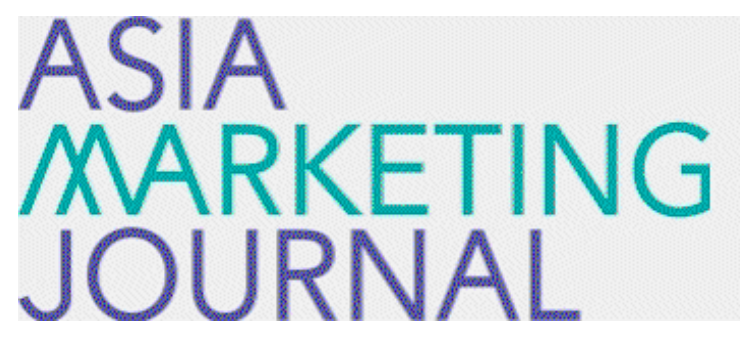

ASIA MARKETING JOURNAL

Volume 5 | Issue 4

Article 1

$12-25-2003$

\title{
시장 진입순서 연구에 관한 톻합적 접근
}

서일 채

준상 여

계숙 한

Follow this and additional works at: https://amj.kma.re.kr/journal

Part of the Marketing Commons

\section{Recommended Citation}

채, 서일; 여, 준상; and 한, 계숙 (2003) "시장 진입 순서 연 구에 관한 톨합적 접근," Asia Marketing Journal: Vol. 5 : Iss. 4 , Article 1.

Available at: https://doi.org/10.53728/2765-6500.1112

This Article is brought to you for free and open access by Asia Marketing Journal. It has been accepted for inclusion in Asia Marketing Journal by an authorized editor of Asia Marketing Journal. 


\title{
시장 진입순서 연구에 관한 통합적 접근 : 향후 연구 방향 제안을 중심으로"
}

\section{Order of Market Entry : A Conceptual Synthesis and Future Research}

\author{
채서일 (고려대학교 경영대학 교수) \\ schaiygikorea.ac. kr \\ 여준상 (고려대학교 경영대학 박사과정) \\ komark6korea.com \\ 한계숙 (고려대확교 경영대학 박사과정) \\ ga iabedreamwiz.com
}

\begin{abstract}
본 연구는 지금까지 학계에서 꾸준히 연구되고 있는 시장진입 순서의 효과에 관한 광 범위한 문헌고찰을 통해 이제까지의 연구들을 유기적 - 인과적으로 연결시킬 수 있는 통합 적인 틀을 제시하고, 기존 연구의 한계점울 바탕으로 진입순서 연구에 관한 새로운 접근을 시도하고자 하였다. 이를 위해 기존 연구를 크게 선발이점 발생에 관한 연구, 후발이점 발 생에 관한 연구, 진입순서 효과에 영항을 미치는 조절변수에 관한 연구, 진입순서 의사결 정에 영향을 미치는 선행변수에 관한 연구로 구분하고 각 부분별 문제점과 향후 연구방향 을 도출하였다. 먼저, 기존 연구에서 선 - 후발 진입에 대한 정의와 기업이 속해있는 시장 에 대한 정의가 불분명하게 이루어짐에 따라 그 효과가 매우 다르게 나타나고 있음을 지적 하고, 동시에 효과가 나타나게 되는 메커니즘도 사후적인 해석 관점에서 이루어지고 있음 을 지적하였다. 이 외에도 진입순서 효과에 영향을 미치는 조절변수에 관한 연구가 생산자 관점에서 주로 다루어져 실제로 제품을 소비하는 수요자의 특성을 감안한 연구가 필요함을 제시하였으며, 진입순서 의사결정에 영향을 미치는 선행변수로 자원기반 관점 요인과 시장 - 경쟁 요인뿐만 아니라 조직의 특성에 대한 연구가 고려되어야 함을 지적하였다. 마지막 으로 진입순서 외에도 후발기업의 진입시차에 관한 추가적인 연구의 필요섬을 언급하였다.
\end{abstract}

* 논문접수 : 03.09 게재확정 : 03.12

본 논문은 고려대학교 교내 톡별 연구비 지원을 받아 연구되었음. 


\section{1. 연구 배경 및 목적}

그 동안 시장 진입순서(order of entry)는 학계의 연구자나 기업의 실무자에게 중요한 주 제로 다루어겨 왔다. 오랫동안 살아 남아 시장의 리더가 되는 브랜드가 있는 반면, 제대로 역량 한번 펼쳐보지 못한 채 잊혀지는 브랜드들도 많은데 많은 연구자들은 이러한 현상이 시장 진입순서와 밀접한 관련이 있다고 보아 왔다(Lieberman and Montgomery 1988).

시장의 초기진입은 물리적, 기술적인 면뿐만 아니라(Lieberman and Montgomery 1988), 소 비자의 인식 면에서도 해택을 부여 받는 경향이 있다(Carpenter and Nakamoto 1989; Schmalensee 1982). 선발기업은 보다 나은 입지와 노동력을 획득할 수 있고 특허보호로 인 한 경쟁상의 이점을 제공받을 수 있으며 소비자들로부터 높은 인지와 명성을 획득할 수 있 다. 그러나 이러한 초기진입에 따른 이점은 신시장의 개척으로 야기되는 위험성을 내포하고 있어 기술과 소비자에 대한 불확실성(Lieberman and Montgomery 1988), 낮은 가격으로 진입 하는 후발기업의 모방(Lilien and Yoon 1990) 혹은 혁신에 의해 쉅게 허물어질 수도 있다 (Shankar, Carpenter, and Krishinamurthi 1998). 따라서 시장진입과 관련된 의사결정은 너 무 이른 진입에 따른 위험과 너무 늦어 잃어버리게 되는 기회사이에서의 균형이 필요하며, 다양한 관점에서 기업의 내·외부적 영향력을 고려하여 선택해야 하는 중요한 사안이다.

그 동안 많은 연구들이 시장진입과 관련된 주제들을 다루어왔지만 초기의 연구들은 주로 시장의 선발진입이 기업의 성과에 미치는 영향을 살펴보았다(Bond and Lean 1977, 1979; Carpenter and Nakamoto 1989; Flaherty 1983; Miller, Gartner, and Wilson 1989; Parry and Bass 1990; Ramkin 1988; Robinson 1988; Robinson and Fornell 1985; Srinivasan 1988; Stipal 1983; Urban, Carter, Gaskin, and Mucha 1986; Whitten 1979). 그러나 이후 의 몇몇 연구들은 기존의 선발기업 이점과 관련된 연구들이 개념적, 방법론적으로 문제점이 있음을 지적하면서 선발자들의 이점이 너무 과장되어 있다는 비판을 하기에 이르렀다 (Golder and Tellis 1993; Schnaars 1994; Tellis and Golder 1996). 이들은 기존 연구결과 와 달리 선발 진입이 항상 성공을 가져다 주는 것은 아니며, 후발진입에 비해 성과가 높지 않을 수 있음을 보여주고 있다(Fershtmen, Mahajan, and Muller 1990; Lilien and Yoon 1990). 이러한 상이한 연구결과를 토대로 Kerin, Varadarajan, and Peterson(1992)은 선발 이점을 보다 명확히 이해하기 위해서 선발진입의 주 효과뿐만 아니라 다양한 상황 변수들과 의 상호작용효과를 고려해야 할 필요가 있음을 지적하였으며, Szymanski, Troy, and Bharadwaj(1995)은 메타분석을 통해 실증적으로 규명함으로써 선발이점의 효과에 대해 보다 심충적인 시사점을 제시하였다.

한편, 시장진입과 관련된 의사결정은 기업의 내·외부적인 영향력을 고려하여 결정해야 하는 중요한 사안임에도 불구하고 기존 연구들이 주로 진입시점과 성과간의 관계에 집중되 어 왔음이 지적되면서(Lieberman and Montgomery 1998), 기업의 시장진입순서를 결정짓는 선행변수에 관한 연구들이 제시되었다(Fuentelsaz, Gomez, and Polo 2002; Schoenecker and Cooper 1998, Thomas 1996). 이러한 연구들을 필두로 하여, 최근 들어서는 인터넷의 성장과 함께 인터넷에서의 시장진입순서 효과를 탐색한 연구(손용석, 김용준과 임양환 2001, 최진 아 2000), 선발 기업의 진입장벽이 기존기업의 성과에 미치는 다양한 프로세스를 규명한 연 구(Han, Kim, and Kim 2001), 혁신적 신제품의 다양한 진입전략과 제품 확산속도( take-off time)간의 관계를 조절하는 변수로서 진입순서에 관한 연구(Montaguti, Kuester, and Robertson 2002)와 같은 다양한 주제들이 제시되고 있으며, 우리나라의 경우 후발기업 스스 
로가 자원에 근거한 다양한 전략 및 창조적인 모방과정을 통해 우위를 획득해 나가는 바발 기업의 선발이점 극복방안에 관한 연구들이 이루어지고 있는 추세이다(이문성과 최이규 2002 ; 이윤철과 이동현 1998,1999 ; 전인수와 김주환 2001; 하영원과 서찬주 1999).

이처럼 시장 진입순서 연구는 Bain(1956)의 연구 이래, 다양한 주제를 바탕으로 활발하게 이루어져 온 만큼 기존 연구들을 종합하는 연구의 분석 틀이 필요하며 이를 바탕으로 그 동 안에 연구된 분야를 확인하고, 심층적 관점의 재접근이 필요한 분야와 새롭게 접근해야 할 분야를 밝히는 연구가 요구되고 있다. 그러나 아쉽게도 Kerin et al.(1992)의 연구 이후 통 합적 관점에서 기존 연구들의 정리를 시도한 연구는 거의 없는 실정이며, 우리나라의 경우 는 전무하다고 해도 과언이 아니다. 특히, 마케팅 분야에서 시장진입 순서효과 연구를 정리 한 대표적 연구라 할 수 있는 Kerin et al.(1992)의 연구는 선발이점의 주효과 뿐만 아니라 상호작용효과의 고려가 선발이점의 설명력을 높일 수 있음을 지적하고, 선발우위의 효과를 조절하는 상황 변수들을 제시하였다는 점에서 그 가치가 높다고 할 수 있으나, 그 주제가 선발이점과 성과간의 관계에 한정되어 있다는 지적을 피하기 어려우며 진입순서효과를 조절 하는 변수들도 주로 생산자 관점에서만 다루어졌다는 한계점을 지니는 것이 사실이다.

이에 본 연구는 지금까지 꾸준히 연구되고 있는 진입순서에 관한 광범위한 국내·외 문 헌고찰을 통해 연구의 흐름을 정리하고, 이제까지의 연구들올 인과적으로 연결시킬 수 있는 통합적인 접근 틀을 제시하고자 한다. 더불어 이러한 통합적인 틀올 바탕으로 기존 연구에 서 누락되고 있는 연구 주제들을 발견함으로써 향후 연구방향에 관한 새로운 관점을 제시, 연구의 발전가능성을 모색하고자 한다. 본 연구에서는 먼저 기존 연구를 크게 선발이점에 관한 연구, 후발이점에 관한 연구, 진입순서효과에 영향을 미치는 조절변수에 관한 연구, 진입순서 의사결정에 영향을 미치는 선행변수에 관한 연구로 구분하여 살펴보고 통합적인 틀을 제시하고자 한다. 다음으로 기존 진입순서 연구들이 지적하고 있는 개넘적, 방법론적 문제점과 본 연구에서 파악한 과거 연구들의 암묵적인 가정과 한계점을 바탕으로 향후 연구 방향에 대해 타진해 보고자 한다. <그림1>은 지금까지 진행되어온 시장 진입순서에 대한 연 구와 앞으로 추가적인 접근이 필요한 연구 분야를 정리해 놓은 시장 진입순서 연구에 관한 통합적 분석 틀이다.

<그림1> 시장 진입순서 연구에 관한 통합적 분석 틀

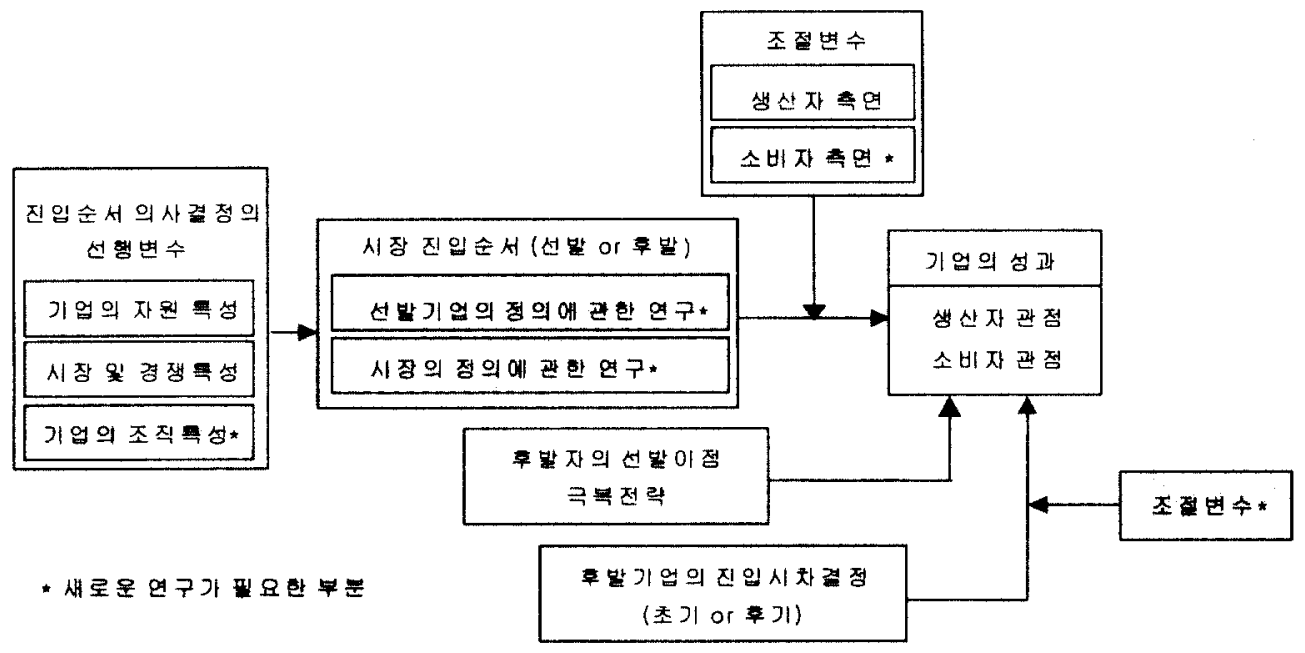




\section{2. 시장 진입순서와 관련된 기존 연구 고찰}

시장 진입순서와 관련된 기존의 연구 흐름들을 구체적으로 살펴보면, 선발이점 발생에 관 한 연구, 후발이점 발생에 관한 연구, 진입순서 효과에 영향을 미치는 조절변수에 관한 연 구, 진입순서 의사결정에 영향을 미치는 선행변수에 관한 연구 등 크게 4 가지 영역으로 구 분할 수 있다(<표 1> 참조). 이들 흐름은 학문적인 연구뿐 아니라 실무에의 적용에 있어서 도 많은 영향력을 가져왔다. 각 영역별로 주요 연구들을 살펴보면 다음과 같다.

\section{1 선발이점의 발생에 관한 연구}

전통적으로 기업의 시장 진입순서에 관한 연구들은 선발기업이 많은 이점을 가진다고 주 장한다. 초기의 연구들은 선발진입 자체가 필연적으로 후발진입에 비해 높은 성과를 가져다 준다고 보는 시장 결정론적 시각을 취하고 있으나, 보다 최근에 이루어진 연구들은 이러한 시각에서 탈피하여 왜 선발진입이 기업의 성과에 영향을 미치게 되는가에 대한 내·외부적 인 메커니즘과 그 원인에 대한 규명이 조심스럽게 이루어지고 있는 추세이다(Makadok 1998; Robinson 1988; Robinson and Min 2002). 본 절에서는 이러한 선발이점 발생에 관한 연구 를 크게 공급측면에서의 이점인 생산자 관점과 수요측면에서의 이점인 소비자행동 관점으로 나누어 살펴보고자 한다.

\section{1 .1 생산자(기업)관점에서의 선발이점 발생에 관한 연구}

생산자, 즉 기업 관점에서 선발자의 이점은 기본적으로 시장에 처음으로 제품(서비스)을 공급함으로써 얻게 되는 경제적인 혜택과 관련이 있는데, 이는 진입장벽 효과에 기초하여 설명되고 있다. 진입장벽은 한 산업 내에서 일련의 구조적인 톡성이 잠재 경쟁자의 시장진 입에 불리하게 작용함을 기본 전제로 하는데, 이러한 메커니즘은 새로운 경쟁을 저지하는 역할을 하기 때문에 기존 기업은 이례적이고 장기적인 수익을 힉득할 수 있다(Bain 1956).

실제로 Bain(1956)이 선발기업이 획독할 수 있는 진입장벽으로서 규모의 경제, 차별화, 비용우위를 언급한 이래 이 개념은 많은 연구들에 의해 확대-적용되어 왔다. Porter(1985) 는 선발기업은 비용우위, 차별화우위의 원천을 다른 기업보다 빨리 확보함으로써 선발이점 을 향유할 수 있다고 주장하였고, Day(1984)도 이와 더불어 선발이점의 원천으로 유통에의 접근성, 독점적 자산의 선점을 언급하였다. Lieberman and Montgomery(1988)는 기존 문헌연 구를 통해 진입장벽 효과를 얻을 수 있는 선발이점의 원천을 정리하였는데, 여기에는 학습 효과 및 R\&D나 특허 등을 통한 기술적 리더십, 희소자원의 선점, 지역적 포지션이나 제품특 성 포지션의 선점 등이 있다고 보았다.

Prescott and Visscher(1977)는 선발진입으로 기업은 보다 폭 넓은 제품라인을 개발할 수 있는 기회를 획득할 수 있다고 보았으며, White(1983)는 폭 넓은 제품라인으로 인해 선발기 업은 소매점 진열대의 주도적 확보가 가능하다고 하였다. 한편, Von Hippel(1984)은 이러한 진입장벽이 결과적으로 후발기업과의 리드타임을 늘리기 때문에 선발기업은 경쟁이 없는 기 간 동안의 독점적 지위를 통해 높은 이윤을 향유할 수 있고, 후발자가 시장에 진입한 후라 도 확고한 시장지위와 경험곡선 효과를 통해 높은 시장점유율을 유지할 수 있다고 보았다. 
<표 1> 진입순서 효과와 관련된 기존 연구들의 분류

\begin{tabular}{|c|c|c|c|}
\hline \multicolumn{2}{|c|}{ 구분 } & 이른적 연구 & 실중적 연구 \\
\hline \multirow[t]{2}{*}{$\begin{array}{l}\text { 선발이점 } \\
\text { 발생 }\end{array}$} & $\begin{array}{l}\text { 생산자 } \\
\text { 관점 }\end{array}$ & $\begin{array}{l}\text { Bain(1956) } \\
\text { Prescott and Visscher (1977) } \\
\text { White(1983) } \\
\text { Day (1984) } \\
\text { Von Hippel (1984) } \\
\text { Porter (1985) } \\
\text { Lieberman and Hontgomery (1988) } \\
\text { Scherrer and Ross (1990) } \\
\text { Kerin, Varadrajan, and Perterson(1992) }\end{array}$ & $\begin{array}{l}\text { Bond and Lean(1977) Whitten(1979) } \\
\text { Robinson and FornelI (1985) } \\
\text { Urban, Carter, Gaskin, and Mucha(1986) } \\
\text { Lamkin(1988) Robinson(1988) } \\
\text { Srinivasan(1988) Lamkin and Day (1989) } \\
\text { Miller, Gartner, and Wilson(1989) } \\
\text { Parry and Bass (1990) } \\
\text { Kalyanaram and Urban(1992) } \\
\text { Brown and Lat tin(1994) } \\
\text { Huff and Robinson(1994) } \\
\text { Robinson, Kalyanaram, and Urban(1994) } \\
\text { Makadok(1998) Robinson and Min(2002) }\end{array}$ \\
\hline & $\begin{array}{l}\text { 소비자 } \\
\text { 관점 }\end{array}$ & $\begin{array}{l}\text { Schmalensee(1982) } \\
\text { Peterson(1982) } \\
\text { Carpenter and Nakamoto(1989, 1990) } \\
\text { Hauser and Wernerfelt (1990) } \\
\text { Kerin. Varadrajan, and Perterson(1992) }\end{array}$ & $\begin{array}{l}\text { Lane(1980), Kalyanaram and Urban(1992) } \\
\text { Kardes and Kalyanaram(1992) } \\
\text { Alpert, Kamims, and Graham (1992) } \\
\text { Kardes, Kalyanaram, Chandrashekaran, } \\
\text { and Dornof f(1993), } \\
\text { Alpert and Kamins(1995) Kardes(2002) }\end{array}$ \\
\hline \multirow[t]{2}{*}{$\begin{array}{l}\text { 후발이점 } \\
\text { 발생 및 } \\
\text { 선발이점 } \\
\text { 극복전략 }\end{array}$} & $\begin{array}{l}\text { 후발이점 } \\
\text { 발생 }\end{array}$ & $\begin{array}{l}\text { Guasch and Weiss (1980) Yip(1982) } \\
\text { Porter (1985) Schnaars (1986) } \\
\text { Lieberman and Montgomery (1988) } \\
\text { Fershtman, Mahajan, and Muller (1990) } \\
\text { Kerin, Varadrajan, and Peterson (1992) } \\
\text { Golder and Tellis (1993) } \\
\text { Berndt, Bui, Dei ley, and Urban(1995) } \\
\text { Carpenter and Sawhey (1996) } \\
\text { Markides (1997, 1998) }\end{array}$ & $\begin{array}{l}\text { Cooper and Schendel (1976) Cooper (1979) } \\
\text { Glazer (1985), Li ieberman (1989) } \\
\text { Lilien and Yoon(1990) } \\
\text { Anderson and Tushman (1990) } \\
\text { Sanbonmat su, Kardes, and Gibson (1991) } \\
\text { Sull ivan(1992) } \\
\text { Zahra, Nash, and Bickford (1995) } \\
\text { Shankar, Carpenter and Krishinamurthi (1998) } \\
\text { Mantel and Kardes (1999) Kardes (2002) }\end{array}$ \\
\hline & $\begin{array}{l}\text { 선발이점 } \\
\text { 극복전략 }\end{array}$ & $\begin{array}{l}\text { Schnaars(1994), } \\
\text { Golder and Tellis(1996) } \\
\text { Zhang and Markman(1998) } \\
\text { 이윤철과 이동현(1999) } \\
\text { 하영원과 서찬주(1999) } \\
\text { 손용석, 김용준, and 임양휸(2001) }\end{array}$ & $\begin{array}{l}\text { 전인수와 김주환(2001) } \\
\text { 이문성과 최이규(2002) }\end{array}$ \\
\hline \multicolumn{2}{|c|}{$\begin{array}{l}\text { 진입순서효과의 } \\
\text { 조절변수 }\end{array}$} & $\begin{array}{l}\text { Kerin, Yaradrajan, and Perterson(1992) } \\
\text { Rangan and Adner(2001) }\end{array}$ & $\begin{array}{l}\text { Lamkin(1988) Parry and Bass (1991) } \\
\text { Mitchel I (1991) } \\
\text { Szymanski, Troy, and Bharadwaj (1995) } \\
\text { Han, Kim, and Kim(2001) }\end{array}$ \\
\hline $\begin{array}{l}\text { 진입순서 } \\
\text { 선행변 }\end{array}$ & $\begin{array}{l}\text { 결정의 } \\
\text { 수 }\end{array}$ & Lieberman and Mont gomery (1998) & $\begin{array}{l}\text { Nitche!I(1989), } \\
\text { Robinson, Fornell, and Sullivan(1992) } \\
\text { Green, Barclay, and Ryans (1995) } \\
\text { Thomas (1996) } \\
\text { Schoenecker and Cooper (1998) } \\
\text { Fuentel saz, Gomez, and Polo(2002) }\end{array}$ \\
\hline
\end{tabular}

기업관점에서의 선발이점을 실중적으로 규명한 연구들은 PIMS 및 ACCESSOR 데이터, 인쇄 매체와 같은 기록(archival)데이터, 패널 데이터, 샘플 서베이와 같은 다양한 방법을 활용 
하고 있지만, 기존 연구들 중 상당수가 PIMS 데이터를 바탕으로 선발기업의 이점을 지지하 여 왔다(Buzzell and Gale 1987; Lamkin 1988; Lamkin and Day 1989; Parry and Bass 1990; Robinson 1988; Robinson and Fornell 1985). 먼저 PIMS 데이터를 활용한 연구에 의하면 선 발기업의 평균 시장점유율은 $29 \%$ 로서 후발 진입기업과 약 $6 \sim 20 \%$ 정도의 차이가 나는 것으로 나타났고, 시장 리더의 $70 \%$ 가 선발기업이라는 결과가 나왔다(Buzzell and Gale 1987). Buzzell and Gale(1987)은 선발기업은 일반적으로 경쟁사보다 제품의 질이 뛰어나고 제품 생산 공정 면에서 많은 특허, 제조비법을 획득할 수 있기 때문에 상당한 시장점유율을 차지 할 뿐만 아니라 시장의 리더가 될 가능성이 크다고 언급하면서 이러한 효과는 제품이 표준 화되어있고 규모의 경제가 크게 나타나는 산업에서 더 유리하다고 보았다. Robinson and Fornel1(1985)과 Robinson(1988)은 각각 소비재와 산업재 시장에서 선발기업이 보다 높은 시장점유율을 보인다는 것을 입증하면서, 이는 선발진입이 기업의 상대적 우위요소(예를 들 면 마케팅 믹스, 제품생산비용)와 전환비용(산업재 시장), 소비자 정보상에서의 우위(소비 재 시장)에 영향을 미치기 때문에 나타나는 결과라 하였다. 이와 함께 Kalyanaram and Urban(1992)은 시계열 스캔 데이터를 이용하여 시장진입순서가 빠를수록 평균 시장점유율이 높다는 것을 실증하였으며, Brown and Lattin(1994)도 34개 소비재에서 129개 브랜드와 미 국의 애완 동물용 식품 브랜드 2 개를 대상으로 조사를 하여 선발브랜드의 시장점유율이 후 발브랜드에 비해 높다는 것을 보여주었다.

한편, Urban, Carter, Gaskin, and Mucha(1986)는 ACCESSOR 데이터에 포함된 24개 카테고 리, 86개 브랜드를 대상으로 분석을 하였는데, 시장진입이 늦어질수록 시장점유율이 감소함 을 보여줌으로써 선발진입의 이점을 실증하였다. Makadok(1998)은 다양한 MMMF(money market mutual fund) 산업의 패널데이터를 활용하여 금윰서비스 산업과 같이 제품 디자인의 모방이 쉽고 진입장벽이 낮은 산업일지라도 백오피스(back office)의 기능, 기존고객에의 접근가능성, 네트웍 구성능력과 같이 특정부분에서 모방하기 힘든 장벽이 있다면 기업은 지 속적 경쟁우위와 함께 선발이점을 누린다고 실증하였다. Robinson and $\operatorname{Min}(2002)$ 은 산업재 시장의 167 개 선발기업과 267 개 초기 후발기업의 생존율을 비교한 결과 선발기업이 후발기 업보다 $18 \%$ 나 높은 $66 \%$ 의 생존율을 기록함을 보여주었다. 이러한 결과는 선발진입에 따른 일시적인 독점, 규모의 경제, 경쟁선점과 같은 선발이점이 시장과 기술의 불확실성에 따른 선발진입의 위험을 상쇄하여 나타나는 현상이라 하였다.

\section{1 .2 소비자행동 관점에서의 선발이점 발생에 관한 연구}

시장에 처음으로 진입하는 선발기업은 물리적, 기술적인 면에서 뿐만 아니라 소비자의 인 식면에서도 혜택을 부여 받는다(Lieberman and Montgomery 1998). 선발기업의 경우, 소비자 인지도와 제품 시용률 면에서 우위를 얻을 수 있으며, 만약 선발 기업 제품에 대한 소비자 들의 경험이 좋다면 대안 선택에 따르는 위험과 탐색 비용의 최소화를 위해 소비자들은 계 속해서 선발 기업 제품을 재구매 하게 된다(Schmalensee 1982). 다른 대안을 선택하는 데에 따르는 심리적 비용은 전환비용으로도 설명이 되는데, 일반적으로 소비자들은 후발기업 제 품으로의 전환비용을 크게 인식하기 때문에 소비자의 심리적 전환비용 최소화 측면에서 선 발기업의 이점이 나타나게 된다(Hauser and Wernerfelt 1990; Lieberman and Montgomery 1988).

소비자 행동 관점에서 선발이점에 대한 초기 실증 연구로는 Lane(1980)의 연구, Kalyanaran and Urban(1992)의 연구 등이 있는데, 선발 진입이 시장점유율이나 이익뿐만 아 
니라 제품의 시용률과 재구매율에도 영향올 미침을 실중하였다. 이 외에도 Alpert, Kamins, and Graham(1992)은 소비자 행동적 관점에서의 이점이 소매점에도 적용될 수 있음올 제시하 였는데, 145 개 식품관련 유통업자를 대상으로 설문 조사하여 실증 분석한 결과 유통업자의 신념, 태도가 후발브랜드에 비해 선발브랜드에 대해 더 호의적이라는 것을 밝혀냈다. Alpert and Kamins(1995)는 소비자 조사률 퉁해 선발브랜드는 후발브랜드에 비해 더 잘 회 상되며, 긍정적 태도와 함께 지속적 구매의도를 이꿀어내는 것으로 나타났다.

한편, 몆몇 연구들은 소비자들의 브랜드에 대한 학습과 선호도 형성 과정이 선발이점 창 출에 중요한 역할을 함을 보여주고 있는데(Carpenter and Nakamoto 1989, 1990; Kardes 2002; Kardes and Kalyanaram 1992; Kardes, Kalyanaram, Chandrashekaran, and Dornoff 1993; Kerin, Varadarajan, and Peterson 1992; Peterson 1982), 톡히 Kardes(2002)는 선발 이점올 맹목적으로 받아들이기 보다는 보다 과학적 관점을 가지고 주도 면밀하게 살펴볼 필 요가 있다고 주장하고 있으며, 선발이점이 왜 발생하며 거기에는 어떠한 심리적 현상이 기 여하는 지에 대해 3 가지 관점의 가능성, 즉 가설이 존재함을 보여주고 있다.

첫 번째는 선천적 이점 가설(inherent advantage hypothesis)인데, 후발자에게서는 나타 나지 않는 독특한 소비자 심리 프로세스를 통해 선발 이점이 나타남을 주장하는 것이다. 단 순히 첫 번쩨라는 사실만으로도 충분한 이점이 창출된다는 것인데, 어떠한 경우라도 앞서 존재한다는 사실은 그렇지 않는 경우에 비해 성공적이라는 것이다. 두 번째는 후천적 노력 이점 가설(enabling advantage hypothesis)인데, 첫 번찌라는 사실은 좋기는 하지만 그것만 으로는 충분치 않다는 것이다. 선발이점은 저절로 나타나는 것이 아니라, 선발자가 효과적 으로 포지셔닝을 하고 광고를 하는 경우에만 나타난다는 것이다. 새로 생겨나는 카테고리의 경우 소비자의 지각 공간은 비어있기에 선발자는 자신의 마음대로 포지셔넝시키는 것이 가 능하며 따라서 후발자에 비해 전략적 기회를 가질 경우가 많아지게 된다는 개념이다. 세 번 째는 위조효과 가설(spurious effect hypothesis)인대, 선발이점은 실제로 나타나는 것이 아니라 다른 이유에 의해 나타난 현상이 마치 선발이점으로 보이는 허상이라는 것이다. 대 부분의 선발브랜드는 방대한 자원을 가진 대형기업에 의해 개발되어지며 따라서 선발이라는 사실은 거대한 판촉, 광고 예산, 강력한 유통 구조를 가진 기업과 상관관계를 가질 수밖에 없고, 그래서 선발이라는 사실은 실제로는 효과가 없는 위조된 효과라는 주장이다. 결국 진 입순서는 아무런 상관이 없다는 것이며, 만약 선발이라는 사실이 회사 크기와 자원과 상관 관계를 가진다면, 선발이 아니라 회사 크기나 자원이 성공을 동인한다는 결론을 이끌어낼 수도 있다는 것이다.

한편 Carpenter and Nakamoto(1989), Kardes and Kalyanaram(1992), Kardes et al.(1993) 둥의 연구에서는 앞서 3 가지 가설 중 선천적 이점 가설에 대한 실증적 지지를 하고 있는데, 이들은 다양한 실험을 통해 소비자 심리 관점에서의 선천적 이점 발생에 관한 메커니즘을 밝히고 있다. 이들의 연구를 종합해보면 다음과 같이 4가지 메커니즘이 정리된다.

우선 Kardes and Kalynaram(1992)의 경우 집합크기효과(set-size effect)에 의해 선발자 의 이점이 나타남을 보여주고 있다. 선발자의 경우 새롭고, 홍미롭기 때문에 소비자들은 이 후 소개되는 후발자와 비교해 볼 때 당연하 더 많은 관심을 쏟게 된다. 따라서 선발자에 대 해서는 더 많이 알게 되고 더 많은 것을 기억하게 되며 결국 이것이 집합크기효과를 발생시 키게 된다는 것이다. 판단 시 가용정보가 많을 경우 더 극단적이고 더 자신감 있는 판단을 하게 된다는 것인데, 일주일 뒤에 소개되는 브랜드보다는 처음 소개된 브랜드에 대해 더 많 은 것을 학습하게 되고 이렇게 더 많은 정보를 알고 있다는 점이 더 높은 선호도를 낳는다 
는 개념이다. 심지어는 나중에 소개된 브랜드가 더 나은 제품임에도 불구하고 첫 번째 소개 된 브랜드가 더 선호되는 놀라운 결과가 나타나기도 했다. 한편 이러한 효과는 3 개 브랜드 가 동시에 제시될 때에는 없어짐올 보여주기도 하였는데, 동시에 노출되면 똑같은 양의 정 보를 학습하게 되며 이로 인해 집합크기효과가 사라지게 된다는 것이다.

이후 Kardes et al.(1993) 연구에서는 앞서의 집합크기효과 외에 고려집합프로세스 (consideration set process)가 선발이점 발생의 원인 메커니즘임을 제시하고 있다. 이 연 구에서는 새로운 제품카테고리에 18 개 브랜드를 제시하고 있는데, 속성 정보가 주어지지 않 은 채 오로지 브랜드만 제시되었기에 집합크기효과는 발생할 수가 없는 상황임에도 피험자 들은 첫 번째 소개된 브랜드를 가장 선호하였다. 첫 번째 브랜드를 소개하고, 일주일 뒤 6 개 브랜드를 소개하고, 또 일주일 후 11 개 브랜드를 각각 소개하고서 기억, 고려, 선택에 대한 소비자 측정을 하였는데 결과는 처음 소개된 브랜드가 단지 처음 소개되었다는 이유하 나만으로 이후 소개된 브랜드를 앞서는 결과가 나타났다.

한편 Carpenter and Nakamoto(1989)는 선발자의 선천적 이점이 나타나게 되는 또 다른 심 리적 프로세스를 보여주었는데, 그 중 하나가 이상점형성 프로세스(ideal point-formation process)이다. 소비자는 새로운 카테고리에 대해서는 낮설며 따라서 선호가 불분명하개 된 다. 이러한 불확실한 상황에서는 선발자와 관련된 특징이나 효익 등이 유용하게 되며 따라 서 선발자는 카테고리의 이상점으로서의 역할을 하게 된다는 것이다. 그리고 이들은 또 하 나의 심리적 메커니즘으로 비교방향성효과(direction-of-comparison effect)를 제시하고 있 는데, 비교방향성효과가 선발자를 기준으로 하여 발생하게 된다는 것이다. 즉 소비자들은 후발자들을 선발자에 맞추어 비교롤 행하게 되며, 따라서 선발자는 독특하고 특별한 것으로 보이지만 후발자들은 단지 선발자의 모방으로 밖에 보이지 않는다는 것이다. 이때의 비교 프로세스에서는 선발자가 기준이 되는 것이다.

이러한 연구들에도 불구하고 Golder and Tellis(1993)는 선발이점은 위조효과, 환상에 불 과하다는 주장을 하였다. 비록 이들은 생존자편향(survival bias)을 지적하였지만, 이들 역 시 비선발자(nonpioneer)에 대한 자료를 얻는 데에는 실패하였다. 만약 실패율이 선발자, 비선발자 모두 비슷하게 높게 나타난다면 이들이 주장하는 과다추정(overestimation) 문제 는 없게 되는 것이다. Kardes(2002)는 이 문제가 향후 연구를 통해 해결되어져야 하며, 이 문제가 해결되기 전까지는 이제까지 그래왔듯이 선발자의 선천적 이점이 지배적 주장으로서 인정될 수밖에 없음을 주장하고 있다.

\section{2 후발이점 발생 및 선발이점 극복에 관한 연구}

한편, 위에서 제시된 선발이점 발생과 대조되는 또 하나의 연구흐름은 후발이점 발생과 선발이점 극복전략에 관한 연구이다. 선발이점 연구와 마찬가지로 후발이점 관련 연구 또한, 초기에는 후발진입으로 인해 주어지는 시장요인(시행착오나 각종 비용회피에 따른 무임승차 호과, 소비자 취향의 변화, 기술의 변화)이나 경쟁요인(기존기업의 관성, 기존기업의 실수, 포지서닝 실패)을 주로 언급하였으나, 최근에 들어서는 후발기업 스스로가 자원에 근거한 다양한 전략 및 창조적인 모방의 과정을 통해 우위를 획득해 나가는 기업요인이 대두되고 있는 실정이다. 이러한 관점은 후발기업이 자신의 불리한 위치를 극복하고 우위를 힉득해 가는 학습 및 전략적 선택의 과정을 중시하는 것인데, 대부분의 기업이 후발주자에 속하는 현실을 감안할 때 전략적인 시사점이 크다고 볼 수 있다. 본 절에서는 후발이점 발생과 관 
련된 기존 연구들을 살펴보고, 최근 우리나라에서 활발하게 진행되고 있는 선발이점 극복전 략에 관한 연구들을 고찰해 보고자 한다.

\subsection{1 후발이점 발생에 관한 연구}

선발이점의 발생과 마찬가지로, 후발이점의 발생에 대해서도 여러 연구들이 다양한 발생 이유를 들고있다. Yip(1982)은 후발진입이 보다 성공적인 기회률 갖는 이유로 기술의 불연 속섬을 들었는데, 후발기업은 시장에서의 기술이 교체되는 시기를 적절하게 활용함으로써 보다 높은 생존기회를 흭득할 수 있다고 언급하였다. 특히 혁신적 후발진입기업은 기존기업 이 구축해 놓은 경쟁의 룰을 바꿈으로서 선발기업을 앞지를 수 있다(Berndt, Bui, Reiley, and Urban 1995; Carpenter, Nakamoto, and Walchli 1997; Carpenter and Sawhey 1996). Porter(1986)는 선발기업의 불리한 요소로 R\&D 비용, 소비자 교육비용, 수요 불확실성, 고 객니즈의 변화, 후발기업의 모방용이성 둥을 언급하면서 후발기업의 상대적 이점을 암시하 였다. Lieberman and Montgomery(1988)의 경우, 후발이점의 원천으로 선발기업의 투자에 대 한 무임승차효과, 환경적 불확실성에 대한 해결, 고객욕구의 변화, 선발기업의 타성 등을 제시하였으며, 이와 비숫하게 Kerin, Varadarajan, and Peterson(1992)은 모방비용, 무임승 차 효과, 범위의 경제, 선발기업의 실수를 통한 학습 등을 후발이점의 원천으로 언급하였다. Markides(1997, 1998)는 기술의 진보로 인한 기술표준의 빠른 변화와 이에 따른 시장·소비 자 욕구의 변화는 혁신적인 후발기업에게 무한한 기회를 준다고 하였다.

후발진입의 이점에 관한 실증적인 연구들을 살펴보면, 먼저 Cooper(1979)는 캐나다 기업 의 195개 신제품 계획에 관한 경영자 조사를 통해 초기 진입에 따른 이점은 초기 진입으로 인한 함정과 불리함으로 인해 거의 상쇄됨을 보였으며, Cooper and Schendel(1976)와 Zahra, Nash, and Bickford(1995)는 혁신적인 후발진입기업에게 기존 기업의 장벽은 거의 효과가 없다는 사실을 실증하였다. Sullivan(1992)은 브랜드를 확장하면서 후발 진입하는 경우에는 강력한 기존 기업이 있더라도 높은 시장점유율을 나타냄을 보였다. 후발이점에 대한 대표적 인 연구자로 꼽히는 Golder and Tellis(1993)는 50개 소비재에 대한 역사적 분석을 통해 새 로운 시장에 최초로 진입한다고 해서 저절로 장기적인 보상을 얻는 것은 아님을 보여주었다. Lilien and Yoon(1990)은 표본조사를 통해 세 번쩨와 네 번쩨 진입자가 첫 번째, 두 번쩨 진입자보다 시장점유율이 더 높음을 보여, 성능이 뛰어난 후발기업의 신제품은 시장 진입의 지연에도 불구하고 높은 시장성과를 누릴 수 있음을 실증하였다.

비교적 최근 연구로 2 개의 의약품에서 13 개 브랜드를 대상으로 실증 분석한 Shanker, Carpenter, and Krishnamurthi(1998)는 혁신적 후발기업이 선발기업에 비해 보다 제른 줌 확산, 시장 잠재력, 반복 구매의 결과를 얻는다고 실증하였다. 저자들은 혁신적 후발제품의 경우, 선발제품의 시장점유율올 잠식하면서 자사의 시장점유율을 증가시킬 수 있는 반면, 선발제품의 마케팅 노력이 자사제품의 확산 정도에 부정적인 영향을 미치지 않는 비대칭적 이점에 기초하고 있기 때문에, 후발기업은 능동적인 포지셔넝과 제품에 높은 수준의 혁신성 을 부여함으로써 선발기업을 앞지를 수 있다고 보았다.

\subsection{2 선발이점 극복 전략에 관한 연구}

Schnaars(1994)는 과거의 연구가 선발이점올 지나치게 강조하고 있는데 대한 문제의식에 서 출발하여, 후발기업으로서 선발기업을 제치고 시장 1 위를 차지하고 있는 기업의 사례률 28 개 제품 카태고리로 나누어 분석올 하였다. 그 결과 후발기업은 저가격 전략, 모방과 개 
량을 통한 고품질전략, 브랜드, 명성, 기존고객, 유통, 재무적 자원과 같은 시장력을 통해 선발기업을 압도하게 된다고 보았다. 1993년에 이미 선발진입의 위험성을 지적하기도 했던 Golder and Tellis(1996)는 후발기업이 선발이점을 극복하고 시장의 리더가 되는데 펼요한 전략적 요인을 (1) 대량 소비시장에 대한 비전, (2) 관리적 지속성을 유지하려는 끈기, (3) 대량 소비시장에 대한 비전에 자산을 지원할 수 있는 재무적 몰입, (4) 부단한 기술혁신, (5) 신규시장으로 자사의 장점을 전환할 수 있는 자산 레버리지 둥으로 분류하면서, 이 요 인들은 구조상 유기적인 상호작용을 통해 기업의 성공을 이끄는 원동력이 된다고 하였다. Zhang and Markman(1998)은 후발기업이 선발이점 극복을 위해 채택해야 하는 전략으로 새로 운 제품카테고리 창출, 기존 제품과 동일한 속성에서의 차별화를 언급하고 있고 있으며, 최 근의 손용석, 김용준과 임양환(2001)의 연구는 후발진입 인터넷 사이트가 선발진입 사이트 에 대항하여 펼칠 수 있는 극복방안으로 비교가능 차이에 의한 차별화 전략, 호감도와 중요 도가 모두 높은 속성에서 비교불가능 차이에 의한 차별화 전략을 제시하고 있다. 이문성과 최이규(2000)는 Schnaars(1994)가 언급한 세 가지 모방전략(차별화, 가격차별화, 시장지배 력)이 후발기업의 경쟁력과 경영성과에 어떠한 영향을 미치는지 상황론적 접근법을 통해 실 증 분석함으로써 유의한 결과를 도출하였다.

우리나라 기업의 사례를 중심으로 실증 분석한 하영원과 서찬주(1999)는 후발브랜드가 선 발이점을 극복하는데 있어 광고의 역할을 4 가지로 분류하고 있는데, 선발브랜드보다 더 우 월한 포지션 전달, 선발브랜드를 압도하는 브랜드 노출, 혁신적 광고전략을 통한 시장 재정 의, 제품·유통-가격전략의 효과를 증폭시켜주는 보조적 역할 둥을 제시하였다. 또 다른 국내 연구인 전인수와 김주환(2001)의 연구는 우리나라에서 50 개 제품 카테고리의 100 개 기 업을 대상으로 실증 분석하였는데, 선발 이점 극복에 효과가 큰 후발기업의 전략으로 마케 팅 커뮤니케이션 노력, 시장력, 진입시차, 포지셔닝 차이성과 방향성, 고품질 전략 둥이 유 의한 것으로 나타났다.

위에서 살펴본 바와 같이 선발이점 극복에 관한 연구는 최근 우리나라에서 많이 이루어지 고 있다(손용석, 김용준과 임양환 2001; 이문성과 최이규 2002; 전인수와 김주환 2001; 하 영원과 서찬주 1999). 여기에는 두 가지 이유가 작용한다고 본다. 우선은 후발기업의 선발 이점 극복 사례가 많이 나타나고 있다는 점을 들 수 있다(전인수와 김주환(2001)에서는 설 중매, $2 \%$ 부족할 때, 로만손, 닥터캡슐; 하영원과 서찬주(1999)에서는 게토레이, 제크, 게보 린, 하이트, 케토톱, 참나무통 맑은소주, 지펠, 애니콜, 매치니코프). 실제로 전인수와 김 주환(2001)의 연구에 따르면, 후발제품이 시장 점유율 1 위를 차지하고 있는 경우가 전체의 $24.5 \%$ 에 이르는 것으로 나타났다. 두 번째는 시장의 대다수 기업이 후발주자인 셈인데 이들 기업이 숫자적으로 보면 주류를 이루고 있기에 이들에 대한 입장에서 전략적 이슈를 제시해 야 한다는 의식이 작용한 것이라고 본다. 앞서 살펴본 선발-후발이점 발생에 관한 연구들 이 사후적 분석 성향이 짙어 결과론적 해석에 가까운 성격을 지닌 반면에, 선발이점 극복전 략에 관한 연구는 사전적 대처차원에서 기업들이 적용하여 인위적 변화를 가할 수 있다는 측면에서 기업에의 시사점이 강하다고 볼 수 있다.

2.3 진입순서와 성과간의 관계에 영향을 미치는 조절변수에 관한 연구

시장 진입순서와 기업 성과간의 보다 명확한 관계를 규명하기 위해서는 다양한 상황적 고려가 전제되어야 한다. Rangan and Adner(2001)는 선발 진입한 기업은 다양한 자원의 선 
점을 통해 진입장벽을 형성할 수 있는데, 선점이 그 효과를 발휘하기 위해서는 최소한 두 가지 상황이 충족되어야 한다고 보았다. 첫쩨, 선발진입에 따른 기회가 충분히 커야한다. 둘째, 제공하는 제품이나 서비스가 더 이상의 차별화가 어려울 만큼 단순한 것이어야 한다. 여기에서 생각해 볼 수 있는 것은 아무리 기업이 선발진입을 하였어도 그러한 이점을 힉득 할 수 있을 만큼의 충분한 시장 규모가 되지 않거나 혹은 다양한 방법으로 제품(서비스)의 차별화가 가능한 경우, 선발기업의 성과는 부정적 영향을 받을 수밖에 없다는 것이다.

Kerin, Varadarajan, and Peterson(1992)은 기존 연구들을 종합, 정리하면서 선발이점의 발생예는 4가지 조절 요인의 고려가 필요함을 주장하였는데, 수요 불학실성, 시장규모, 범 위의 경제 등과 같은 경제적 요인, 선점적 투자, 제품 특성과 같은 선점적 요인, 기술 혁신 의 특성, 기술적 변화와 같은 기술적 요인, 시장의 종류, 시장의 변화, 공유 자산 투자 여 부와 같은 행동적 요인 둥을 그 예로 제시하였다. Szymanski, Troy, and Bharadwaj(1995) 역시 기존 연구에 대한 메타분석을 통해 조절변수의 필요성을 강조하고 있는데, 예를 돌면 제품 라인의 폭이나 마케팅 비용과 같은 조절 변수를 무시하고 진입순서 효과를 분석하면 오류가 나타날 수 있음을 지적하면서 여러 가지 시장 요인과 전략 요인이 진입순서와 성과 간의 관계를 조절함을 밝혔다.

Lamskin(1988)은 다양한 산업이 포함된 PIMS 데이터 분석을 통해, 진입순서와 시장점유율 간의 관계는 사업단위의 전략과 기업의 자원 및 구조에 영향을 받는다는 점을 실증하였고, Parry and Bass(1990)는 선발기업의 이점이 산업 유형과 최종사용자의 구매량에 따라 달라 질 수 있음을 PIMS 자료를 통해 실증하였다. 그리고 Mitchell(1991)은 선발기업이 산업 내 존재하고 있던 기업인지, 새로 그 산업에 진입하는 기업인지에 따라 진입순서의 효과가 다 르게 나타남을 밝혔으며, $\mathrm{Han}, \mathrm{Kim}$, and $\mathrm{Kim}(2001)$ 은 선발진입장벽의 효율성은 후발진입자 의 혁신성에 의해 조절된다고 보았다. 국내연구로는 이문성과 최이규(2002)가 진입시점과 경영성과간의 관계를 조절하는 환경변수를 정리하였는데 이는 시장특성변수(시장집중도, 점 유율, 잠재력, 고객의 구매빈도), 산업특성변수(기술진보속도, 선발기업의 대웅패던, 경쟁 자의 기업규모, 수직적 통합정도), 제품톡성변수(제품의 유사성 및 차별성, 소비재 맟 산업 재), 기업특성변수(기업규모, 기술 및 시장경험, 제품 경쟁력) 둥으로 분류된다고 하였다.

\section{4 시장 진입순서 결정에 영향을 미치는 선행변수에 관한 연구}

시장 진입순서 효과룰 다룬 문헌들을 살펴보면, 진입시점이 기업의 성과에 어떠한 영향을 미치는가에 대해서는 비교적 많은 연구들이 이루어진 반면, 진입시점을 결정짓는 선행변수 에 관한 연구는 전략적인 시사점이 있음에도 불구하고 제한적으로 이루어진 것이 사실이다. Lieberman and Montgomery(1998)는 진입시점과 성과만을 고려하는 기존 연구 시각에서 벗어 4. 선발진입 이점과 자원근거 관점(resource-based view)과의 개념적 연계 펄요성을 역설 하면서 기업의 자원과 역량이 진입 결정에 미치는 영향력을 규명하는 것이 향후 연구에서 필요하다고 강조하였다. Mitchell(1989)의 연구에서는 진입 가능성과 그 시기를 결정짓는 중요 변수로 새로운 시장에서도 가치를 지닐 수 있는 톡화된 자산(specialized asset)을 언 급하였다. 가설검증 결과, 특화된 자산 중 직접판매인력(direct sales force: 유통시스템) 의 소유가 진입시기에 유의한 영향을 미치는 것으로 나타났으며 경쟁자의 증가와 핵심제품 의 위협 또한 기존기업의 새로운 시장진입올 앞당기는 것으로 나타넜다. Robinson, Fornel1, and Sullivan(1992)은 재무적 능력과 내부적 진입모드가 기업의 시장진입을 빠르게 한다고 
보았으며, 강력한 마케팅 기술과 브랜드 자산을 가지고 있는 기업은 오히려 늦게 진입하려 는 경향을 보인다고 하였다. 그러나 R\&D투자는 진입순서에 아무런 영향을 주지 않는 것으로 나타났다. Sullivan(1991)은 확장 브랜드의 진입시기를 조사하였는데, 확고한 고객기반을 지니고 있는 브랜드의 경우, 그렇지 못한 브랬드보다 새로운 시장에 느리게 진입하는 것으 로 나타났다. 이는 빼른 시장진입에 따른 불확실성이 기존 브랜드 자산에 피해를 주는 것을 회피하기 위함이라고 설명하고 있다. Green et al.(1995)은 기업의 진입시기를 결정짓는 변 수로 제품시장의 구조적 특성과 우위 자원을 언급하면서 경쟁자의 수, 관련 산업에서의 경 험, 일반적인 진입경험, 종업원 수, 자본(판매량) 등이 많을수록 기업의 새로운 시장진입 시기가 빨라진다고 보았다.

한편, 한 산업 내에서는 새로운 제품으로의 세대교체가 빈번히 발생하는데 여기에서 제품 변화 정도 또한 새로운 시장으로의 선발진입을 결정짓는 중요한 요소이다. 새로운 제품으로 의 변화가 점진적(incremental)이라면 기존기업은 새로운 시장에 선두로 진입하지만(Thomas 1996), 변화가 급진적(radical)이라면 기업은 자신의 기존 시장에 대한 관성(inertia) 때문 에 신규시장으로의 선발진입을 주저하게 된다(Henderson and Clark 1990). Schoenecker and Cooper (1998)는 기업의 진입순서에 영향을 미치는 선행변수로 기업의 자원적 특성을 언급하 면서 R\&D능력, 유통 네트웍과 같은 가업자원과 현재 시장에서의 위협이 기존기업의 신규시 장 진입을 앞당기는 요소인 반면, 기업의 크기는 의사결정 속도에 부정적인 영향을 미치기 때문에 결과적으로 진입시기를 늦추는 역할을 한다고 보았다. 그러나 이러한 결과는 선발이 점이 크게 나타나는 산업과 그렇지 못한 산업의 차이에 따라 달라진다고 하였다. Fuentelsaz, Gomez, and Polo(2002)는 기존의 연구들이 제품 수준에서만 이루어졌다고 지적 하면서, 소매은행과 같이 지역적 다각화(geographic diversification)가 중요한 산업에서 새로운 지역시장으로의 진입속도에 영향을 미치는 선행변수를 제시하였다. 결과를 보면 기 업의 크기가 클수록, 헌재의 수익성이 높은 기업일수록, 핵심지역 시장의 경쟁자의 수가 많 아질수록 새로운 시장에 진입하는 속도가 딸라지며, 목표로 하는 시장의 잠재 경쟁자가 많 올수록 진입속도는 느려지는 것으로 나타났다. 특히 이들은 앞의 연구자들과 달리 기업의 규모가 상대적인 가용자원의 크기를 의미하기 때문에 신시장 개척과 관련된 시장력을 높여 진입장벽을 극복하는 역할을 수행, 진입을 르게 한다고 보았다.

이상으로 시장 진입순서와 관련된 방대한 기존 연구들을 살펴보았으며, 진입시점과 관련 된 최근의 대표적인 실증연구는 4가지 구분에 맞춰 <표 2>에 별도로 정리하였다(Kerin et al.(1992)과 Szymanski(1995) 연구에서 1995년 이전까지의 선발이점 연구에 대한 리뷰가 이 루어진 관계로, 본 연구에서는 1995년 이후의 연구를 별도의 표로 요약하였다)

연구의 톻합과정에서 기존 연구들 간에 비교적 일관된 결과를 보여주는 연구 영역들도 많 지만, 경우에 따라서는 연구들 간에 혼재된 결과를 보여주면서 지배적 결론을 내리지 못하 는 분야도 있음을 발견할 수 있다. 아울러 개별적 연구 수준에서 제시되는 이론적, 방법론 적 한계점들이 누군가에 의해 체계적으로 정리되지 못하고, 후속 연구에서 오류를 반복·답 습하는 경우도 볼 수 있다. 따라서 다음 장에서는 기존의 몇몇 연구자들이 지적하고 있는 한계점을 살펴보고, 이외에 추가로 해결해야할 문제점들과 이를 발전적 방향으로 개선시킬 수 있는 방안에 대해 논의를 해보고자 한다. 
<표 2> 시장 진입순서와 관련된 처근의 대표적 실증 연구의 요약

\begin{tabular}{|c|c|c|c|c|c|}
\hline & 년구 & $\begin{array}{c}\text { 독립·조절변수 } \\
\text { (종속변수) }\end{array}$ & 연구대상 & 분석방법 & 연구의 결론 \\
\hline \multirow{2}{*}{$\begin{array}{l}\text { 생산자 관점의 } \\
\text { 선발진입 이점 } \\
\text { 에 관한 연구 }\end{array}$} & $\begin{array}{l}\text { Makadok } \\
\text { (1998) }\end{array}$ & $\begin{array}{l}\text { 진입순서, 진입 } \\
\text { 시차, 경쟁자수 } \\
\text { (시장 점유울, } \\
\text { 가격우위) }\end{array}$ & \begin{tabular}{|l|} 
금용산업의 33 개 \\
제품카테고리, \\
1015 개 뮤추얼 먼 \\
드
\end{tabular} & 연립방 & $\begin{array}{l}\text { 진입장벽이 낮고, 모방이 } \\
\text { 쉬운 산업에서도 특정 } \\
\text { 우위자원이 있다면 } \\
\text { 선발이점유지 가능 }\end{array}$ \\
\hline & $\begin{array}{l}\text { Robinson \& Min } \\
(2002)\end{array}$ & $\begin{array}{l}\text { 진입시차, 진입순서 } \\
\text { (생존율) }\end{array}$ & $\begin{array}{l}167 \text { 개 선발기업 } \\
267 \text { 개 후발기입 }\end{array}$ & 로짓 희거분석 & $\begin{array}{l}\text { 선발기업의 생존율이 더 } \\
\text { 크게 나타났으며, 선발 기 } \\
\text { 업의 리드타임이 길수록 생 } \\
\text { 존율이 더 크게 나타남 }\end{array}$ \\
\hline $\begin{array}{l}\text { 소비자 관점의 } \\
\text { 선발진입 이점 } \\
\text { 에 관한 연구 }\end{array}$ & $\begin{array}{l}\text { Alpert \& Kamins } \\
\text { (1995) }\end{array}$ & $\begin{array}{l}\text { 선발, 후발 브랜드 } \\
\text { (태도, 구매행동, } \\
\text { 브랜드희상, 기억) }\end{array}$ & 366명의 소비자 & $\mathrm{t}$-분석 & $\begin{array}{l}\text { 선발 브랙드는 태도와 } \\
\text { 구매의도에서는 긍정적 } \\
\text { 영향, 그러나 브랜드 } \\
\text { 화상이나 기억에서의 } \\
\text { 긍정적 영향은 부분지지 }\end{array}$ \\
\hline $\begin{array}{l}\text { 후발이점에 } \\
\text { 관한 연구 }\end{array}$ & $\begin{array}{l}\text { Shankar, } \\
\text { Capenter, \& } \\
\text { Krishinamurthi } \\
(1998)\end{array}$ & $\begin{array}{l}\text { 혁신적 진입전략 } \\
\text { (제품의 학산, } \\
\text { 브랜드마케팅 미스 } \\
\text { 관련지수) }\end{array}$ & $\begin{array}{l}2 \text { 개의 의약품 } \\
\text { 카테고리, } 13 \text { 개 } \\
\text { 브랜드 }\end{array}$ & 회궈분석 & $\begin{array}{l}\text { 혁신적 후발기업은 } \\
\text { 선발기업에 비해 높은 } \\
\text { 시장잠재력, 재구매, 며론 } \\
\text { 확산을 보임 }\end{array}$ \\
\hline \multirow{2}{*}{$\begin{array}{l}\text { 선발이점 극복 } \\
\text { 에 관한 연구 }\end{array}$} & $\begin{array}{l}\text { 이문성과 최이규 } \\
(2000)\end{array}$ & $\begin{array}{l}\text { 모방전략, } \\
\text { 환경특성(조절) } \\
\text { (경쟁우위 강화 } \\
\text { 성과향상) }\end{array}$ & 113개 후발기업 & 다중회거분석 & $\begin{array}{l}\text { 모방전략은 후발기업의 } \\
\text { 경쟁력과 성과향상에 } \\
\text { 기여하고, 이는 } \\
\text { 환경벽성애 따라 달라짐 }\end{array}$ \\
\hline & $\begin{array}{l}\text { 전인수와 김주환 } \\
(2001)\end{array}$ & $\begin{array}{l}\text { 상황전략, } \\
\text { 포지셔넝 전략, } \\
\text { 마케팅 믹스 } \\
\text { (선발이점극복) }\end{array}$ & $\begin{array}{l}50 \text { 개 제품 } \\
\text { 카테 고리, } 100 \text { 개 } \\
\text { 기업, 후발 제품 } \\
250 \text { 개 }\end{array}$ & 다중회귀분석 & $\begin{array}{l}\text { 상황전략, 포지셔닝 전략 } \\
\text { 은 지지, 마케팅 믹스 중 } \\
\text { 저가격 전략은 지지 안됨. }\end{array}$ \\
\hline \multirow{2}{*}{$\begin{array}{l}\text { 조절변수에 } \\
\text { 관한 연구 }\end{array}$} & $\begin{array}{l}\text { Szymanski. } \\
\text { Troy, \& } \\
\text { Bharadwaj } \\
\text { (1995) }\end{array}$ & $\begin{array}{l}\text { 진입순서, 기존에 } \\
\text { 생략되었던 마케팅 } \\
\text { 변수들, 표본특성, } \\
\text { 측정변수 } \\
\text { (시장 점유율) }\end{array}$ & $\begin{array}{l}\text { PIMS 데이터에서 } \\
\text { 추출된 } 2746 \mathrm{SBU}\end{array}$ & 매타 분석 & $\begin{array}{l}\text { 진입순서는 시장 점유율에 } \\
\text { 직접적인 영향력을 } \\
\text { 지니나, 상호작용을 } \\
\text { 고려한 모델이 더 적합함. }\end{array}$ \\
\hline & $\begin{array}{l}\text { Bowmand } \\
\text { Gat ignon (1996) }\end{array}$ & $\begin{array}{l}\text { 진입순서. 마캐팅 } \\
\text { 믹스변수 } \\
\text { (시장 점유율) }\end{array}$ & $\begin{array}{l}55 \text { 개 브랜드. } \\
3720 \text { 개 제품 }\end{array}$ & 회귀분석 (WLS) & $\begin{array}{l}\text { 시장진입에 따라 마케팅 믹 } \\
\text { 스 변수의 영향력 감소, 시 } \\
\text { 장진입의 주효과는 지지 안 } \\
\text { 뒴. }\end{array}$ \\
\hline $\begin{array}{l}\text { 선행변수에 } \\
\text { 관한 연구 }\end{array}$ & $\begin{array}{l}\text { Schoenecker } \\
\text { Cooper (1998) }\end{array}$ & $\begin{array}{l}\text { 기업의 보유자원 } \\
\text { 기엽의 특성 } \\
\text { (시장친입) }\end{array}$ & $\begin{array}{l}\mathrm{PC} \text { 와 미니컴 큐터 } \\
\text { 산업의 } 108 \text { 개 } \\
\text { 기업 }\end{array}$ & 다중회귀분석 & $\begin{array}{l}\text { 직관유통채녈을 소유하고, } \\
\text { 기업의 R\&D정도와 위협적 } \\
\text { 시장에의 몰입어 높을수록 } \\
\text { 시장진입이 할라짐 }\end{array}$ \\
\hline
\end{tabular}

\section{3. 기존 진입순서 연구들이 지적하고 있는 한계점}

본 장에서는 앞서 살펴본 시장 진입순서와 관련된 연구들에 대해 기존 연구자들이 지적 
하고 있는 한계점을 살펴보고자 한다. 이는 주로 후발이점을 옹호하는 연구자들에 의해 지 적된 문제점들로 선발이점 연구의 방법론적인 면에 많이 치우쳐져 있음을 발견할 수 있다. 최근에는 이와 함께 소비자 측면에서의 진입순서 이점에 관한 연구의 정교화와 향후 추가적 연구의 필요성 등이 대두되고 있다. 좀더 구체적으로 살펴보면 다음과 같다.

첫째, 앞서 언급한 선 - 후발기업의 측정 및 선발진입 이점 측정에 관한 방법론상의 문제 점이다. 즉, 이론상으로 선발진입의 이점이 강력하고 변함이 없을 것처럼 보이지만 실제로 는 지나치게 과장되어 있다는 견해이다(Golder and Tellis 1993; Schnaars 1994). 특히 PIMS 데이터의 경우 수집과 분석이 용이하다는 장점이 있지만, 다음과 같은 문제점이 지적 되고 있는 것이 사실이다.

(1) PIMS 데이터는 성공한 선발기업의 데이터만을 기록하고 있을 뿐 실패한 선발기업은 포함하고 있지 않다는 것이다. 즉 실패한 선발기업은 배제하고 성공한 선발기업들만을 분석 의 대상으로 삼음으로써 모든 선발기업에게 돌아가는 보상을 지나치게 과장하는 생존자 편 향(survival bias)을 보인다는 것이다(Day and Freeman 1990).

(2) PIMS와 ACCESSOR 데이터는 선발기업을 분류하기 위해 단 한 명의 응답자에 의존하는 셀프 리포트(self-report)형식을 취함으로써 그 결과에 대한 신뢰성과 타당성을 검증할 방 법이 없다는 것이다. 실패한 기업을 무시하고 자기 마음대로 자신을 선발기업이라 호칭하는 셀프 리포트 편향은 왜 PIMS 데이터에 있는 기업 중 52\%가 자신을 선발기업으로 분류하는가 에 대한 설명을 대신하고 있다(Buzzell and Gale 1987).

(3) PIMS 데이터는 선발기업을 일찍 시장에 진출한 회사중의 하나, 흑은 초기 연도에 시 장에 진출한 회사라고 정의하고 있는데(Buzzell and Gale 1987), 이는 실제 연구에서 제시 하고 있는 선발기업의 정의와 일치하지 않는다는 것이다. 이는 선발진입(first-mover)의 이 점에 관한 것이 아니라 초기 진입(early entrants)의 이점을 결정할 수 있는 성격의 것이다

(4) PIMS 데이터에 포함된 기업들은 대부분 경쟁적인 상황에서 보는 전형적인 기업을 대 표한다기보다는 대기업간의 경쟁만을 다루고 있다는데 문제점이 있다. 이는 소규모의 모험 적인 선구자들이 유통과 마케팅, 자금 면에서 엄청난 경쟁적 우위를 갖고 있는 거대한 후발 진입 기업들에 맞서서 어떻게 경쟁해 나가야 하는가에 대한 실마리를 주지 못하고 있다 (Schnaars 1994). 이에 Vanderwerf and Mahon(1997)은 22개 개별적인 연구의 90개 테스트 를 포함한 샘플 데이터의 메타 분석을 통해 기존의 선발진입효과에 관한 연구들이 방법론상 의 문제점이 있음을 지적하였다. 구체적으로는 생존자 편향과 함께 종속변수로서 시장점유 율만을 사용, 조사자에 의해 선발진입 이점이 보다 강하게 나타나는 산업들이 편중되어 선 택, 진입자(entrants)의 역량에 대한 통제 실패를 이유로 들었다. 이들은 위의 방법으로 선 발진입과 성과간의 관계를 조사하면 약 $99 \%$ 가 긍정적인 관계를 보이는 반면, 이 방법들 모 두 사용하지 않고 조사하게 되면 단지 $8 \%$ 의 긍정적 관계만을 관찰할 수 있다고 주장함으로 써 선발진입 연구의 결과 해석 시 주의할 것을 언급하였다.

둘째, 선 - 후발진입의 이점에 관한 연구들은 기업성과의 유효기간을 어느 정도로 정의할 것인가에 대한 체계적인 접근이 부족하다는 것이다(Kalyanaram, Robinson and Urban 1995). 예를 들어 초기 몇 년 동안의 짧은 기간을 바탕으로 하면 선발기업은 수요와 기술의 불확실 성 때문에 후발기업보다 낮은 생존율을 보일 수 있지만, 일단 초기의 불확실한 기간을 넘기 고 난 선발기업은 보다 장기적인 생존율을 나타낼 수 있다(Golder and Tellis 1993). 따라 서 앞으로의 연구는 기업 성과의 판단에 있어서 단기적 관점과 장기적 관점 중 어느 것이 바람직한지를 규명해야 할 것이다. 진입순서에 따른 성과의 측정이 어느 시점에서 이루어지 
냐에 따라 사뭇 다른 결과가 나올 수 있기 때문이다.

쎗째, 생산자 관점에서 진입순서의 이점에 관한 연구는 활발히 이루어진 반면, 소비자 측 면에서의 접근은 아직까지 정교화될 부분이 많으며, 상대적으로 많이 이루어지지 않았다는 점을 들 수 있다(Alpert and Kamins 1995). 특히, Alpert and Kamins(1995)는 소비자들이 선발브랬드에 대해 보다 긍정적인 태도를 보이는 연구결과가 선발브랜드는 긍정적인 의미를 함축하고 있고, 후발브랜드는 부정적인 의미를 함축하고 있다고 생각하는 응답자편향효과 (demand effect)에 의한 결과일 수 있음을 지적하였다. 또한 소비자들이 어떠한 경우에 특 정 브랜드를 선발 브랜드로 오인하는지, 브랜드의 선발진입시 문화적인 차이가 연구결과에 어떠한 영향을 미치는지에 대한 연구가 필요하다고 역설하였다. 한편, Carpenter Lehmann, and Nakamoto (1997)의 연구에서는 선발진입을 통해 소비자의 선호패턴을 자사에 유리하도록 형섬할 수 있지만, 동시에 재포지셔넝(repositioning)의 어려움을 지적하고 있는데, 이는 선발진입으로 인한 소비자 인식상의 불리함은 후발진입 기업에계 기희로 작용할 수 있음을 시사하고 있다. 이들의 지적을 미루어 짐작하건데, 선발제품은 전형제품(prototype)으로 인 식되고 소비자들의 고려대상군(consideration set)에 먼저 포함되는 혜택을 누릴 수 있지만, 실제로 구매가 바로 일어나지 않는 경우라면, 제품구매 시 나온 지 오래된 제품으로 인식되 거나 혹은 단순한 준거제품으로서의 역할만을 수행하는 불이익을 당할 수도 있을 것이다.

이상으로 기존의 진입순서 연구들에 의해 지적된 한계점올 살펴보았다. 다음 장에서는 본 장에서 지적된 문제점들과 함께, 본 연구에서 새롭게 제시하는 기존 연구의 한계점을 바탕 으로 향후 연구방향에 대해 논의해 보고자 한다.

\section{4. 본 연구에서 제시하는 한계점과 향후 연구 방향}

\section{1 선발진입의 정의에 관한 연구 : 누가 선발기업인가?}

시장 진입순서 효과에 관한 기존 연구들은 위에서 살펴본 바와 같이 매우 상이한 결과들 을 제시하고 있다. 이렇게 상이한 결과들이 나타나는 원인으로서, 가장 우선적으로 생각할 점은 선발기업(first-mover)을 어떻게 정의할 것인가의 문제이다.

이미 앞에서 PIMS 데이터를 활용함으로써 선발진입의 이점을 지지한 많은 연구들이 연구 의 개념적 정의와 조작적 정의가 일치하지 않는 실수를 범하였고, 이로 이해 선발기업의 이 점이 왜곡되어 부풀려질 수밖에 없는 이유를 제시하였다(Alpert and Kamins 1995; Golder and Tellis 1993; Kerin, Varadarajan, and Perterson 1992). 다시 상기하자면, PIMS 데이 터는 선발기업의 정의를 일찍 시장에 진출한 회사중의 하나 혹은 초기 년도에 시장에 진출 한 회사라고 정의하고 있는데(Buzzell and Gale 1986), 이는 대부분의 연구에서 선발기업을 시장에 처음 진입한 기업이라 정의한 것과 일치하지 않을 뿐만 아니라, 실패한 기업은 포함 하지 않은 생존자 편향(survival bias)된 자료이기 때문에 선발기업의 이점이 과대평가 된 다고 보았다.

Golder and Tellis(1993)는 이러한 기존연구의 문제점을 지적, 선발기업은 새로운 제품군 에서 (1) 중요한 기술이나 특허를 처음 개발한 기업(innovator), (2) 샘플이나 작동 가능한 모델을 처음 개발한 기업(product pioneer), (3) 제품을 시장에 처음 팔기 시작한 기업 
(market pioneer) 등으로 구분할 수 있지만, 이중 제품을 시장에 처음 팔기 시작한 기업 (market pioneer)이 선발기업(first-mover)의 정의에 적절하게 사용될 수 있다고 보았다. 이는 기존의 많은 연구들이 새로운 시장에 제품을 가지고 처음 진출한 기업을 선발기업이라 정의하는 것과 일치하는 것이다(Lieberman and Montgomery 1988; Robinson and Frnell 1985; Schmalensee 1982; Urban, Carter, Gaskin, and Mucha 1986).

그러나 이 정의 또한 많은 문제점을 지니고 있는 것이 사실이다. Schnaars(1994)는 28개 의 기술혁신이 처음 시장에 나와서 많은 소비자들의 홍미를 끌게 되기까지의 시간을 조사하 였다. 그 결과, 보통 비내구재에서 내구재에 이르기까지 최초의 상업적인 진입과 최초의 상 업적인 성공사이에 짧게는 5 년에서 많게는 40 년의 시차가 있으며, 이 기간 중에 수많은 기 업들이 시장에 진입하였다가 떠나곤 한다는 것을 발견하였다. 여기에서 중요한 것은 시장에 처음 진입한 기업이 처음 성공한 기업은 아니라는 것이며, 처음 진입한 기업일지라도 시장 에서 사라져간 기업이라면 소비자들은 그 기업을 전혀 모를 수도 있음을 내포하고 있다.

선발 진입일지라도 소비자들이 선발기업의 존재 자체를 인식하고 있지 못하고 있는 상황 이라면 이 기업은 선발기업어 될 수 없다. 왜나하면, 소비자 관점에서 선발진입에 따른 이 점으로 많은 연구들이 높은 인지도와 선호도, 이미지와 평판 등을 언급하고 있는데 (Carpenter and Nakamoto 1990; Schmalensee 1982), 이는 최소한 소비자들이 그 선발기업의 제품이 시장에 있음을 알고 있다는 가정(assumption)을 전제하고 있기 때문이다. 일반적으 로 선발기업에 대한 정의를 내릴 때 소비자의 인식유무를 전혀 고려하지 않고 실패하여 죽 어버린 기업이라도 선발기업이라 정의하는 것은 소비자 관점에서의 선발기업 개념을 무시하 는 것이다.

Schnaars(1994)는 선발기업을 한 제품을 시장에 내놓은 기업들 중에서 그 제품으로 성공 을 거둔 기업과 그 이전의 모든 기업 을 포함하는 것으로 정의하였는데, 이는 실패한 선발 기업도 포함함으로써 PIMS 데이터가 지니고 있는 생존자 편향의 한계점을 극복함과 동시에 Golder and Tellis(1993)가 보지 못한 소비자 관점에서의 선발기업의 정의를 어느 정도 포 괄함으로써 기존의 문제점을 상당히 극복했다고 할 수 있다. 그러나 여기에서 성공의 기준 을 어디에 둘 것인가는 매우 민감한 문제로 대두될 수 있다. 왜냐하면 성공의 기준 (criteria)으로는 소비자 인지의 유무, 선호, 구매의도, 시장점유율, 매출액, 수익성 등 여 러 가지가 제시될 수 있으며, 그 수준(degree) 또한 어느 정도로 보는가에 따라 결과변수에 직접적인 영향을 미치기 때문이다.

또한 Schnaars(1994)는 후발진입자(late entrants)를 초기추종자(early adaptor)와 후기 추종자(late adaptor)로 나누고 있는데, 그가 앞서 정의를 내린 선발기업 중 최초 성공기업 에는 초기추종자가 포함될 가능성을 내포하고 있다. 이 경우 선발기업과 후발기업의 정의가 동시에 적용이 되는 기업이 나타날 수 있다. 따라서 선발기업에는 초기추종자이면서 해당 시장에서 최초로 성공한 기업까지 포함시키고, 후발기업에는 최초 성공기업 이후의 조기추 종자와 후기추종자를 포함한다는 새로운 선 ·후발 정의가 필요할 것으로 판단된다.

따라서, 앞으로의 향후 연구에서는 개별 연구들의 개념적, 조작적 정의에 따라 어떠한 결과가 나타나는가를 신중히 고려하여 그 결과의 해석과 적용에 신중을 기함과 동시에, 연 구들마다 다양하게 제시하고 있는 선발기업에 대한 정의를 좀더 정교화할 필요가 있다. 다 만 현재까지의 연구를 분석한 결과, 본 연구에서는 Schnaars(1994)의 접근방법이 생존자 편 향과 소비자관점의 선도 개넘 무시라는 오류를 극복할 수 있다는 측면에서 지금까지의 선발 진입의 정의로 가장 적절하다고 보여지며, 앞서 지적한 성공 기준 명확화와 선·후발 규정 
의 명확성을 부여한다면 가장 훌륭한 선발진입 기업의 정의가 될 것이라 본다.

더불어 진입순서효과를 규명하는데 있어 Golder and Tellis(1993)는 생존자편향 (survival bias)문제를 해소하기 위해 선발기업의 실패율을 고려해야 한다고 주장하고 있는 데 여기에서 더 나아가 선발기업의 실패울뿐만 아니라 후발기업의 실패율율 동시에 고려하 고 이를 비교한다면(Kardes 2002), 선발이점이 과다추정(overestimation)되는 문제를 어느 정도 해결합으로써 보다 명확한 진입순서 호과의 검증이 가능하리라 본다. 우리나라의 경우 신용평가정보사에서 매년 발행하는 기업연감자료를 보면 상장, 등록법인뿐만 아니라 비상장, 외감법인까지도 포함되어 있는데 여기에는 매넌도 각 기업들의 신출입여부, 매출 데이터 둥 이 기록되어 있다. 이를 통해 언제 기업들이 시장에 진입하고 사라져갔는가에 대한 시계열 적인(longitudinal) 자료와 각 제품카테고리별 선발기업과 후발기업에 대한 객관적인 자료 를 획득하는 것이 가능하다. 따라서 이러한 데이터를 적절하게 활용하여 진입순서효과를 검 증한다면 실패한 기업의 자료획득의 어려움으로 인해 필연적으로 발생하는 생존자 편향문제 를 해결할 수 있을 것이다.

<그림 2> 기존 연구들의 선발진입 기업 정의와 그 문제점

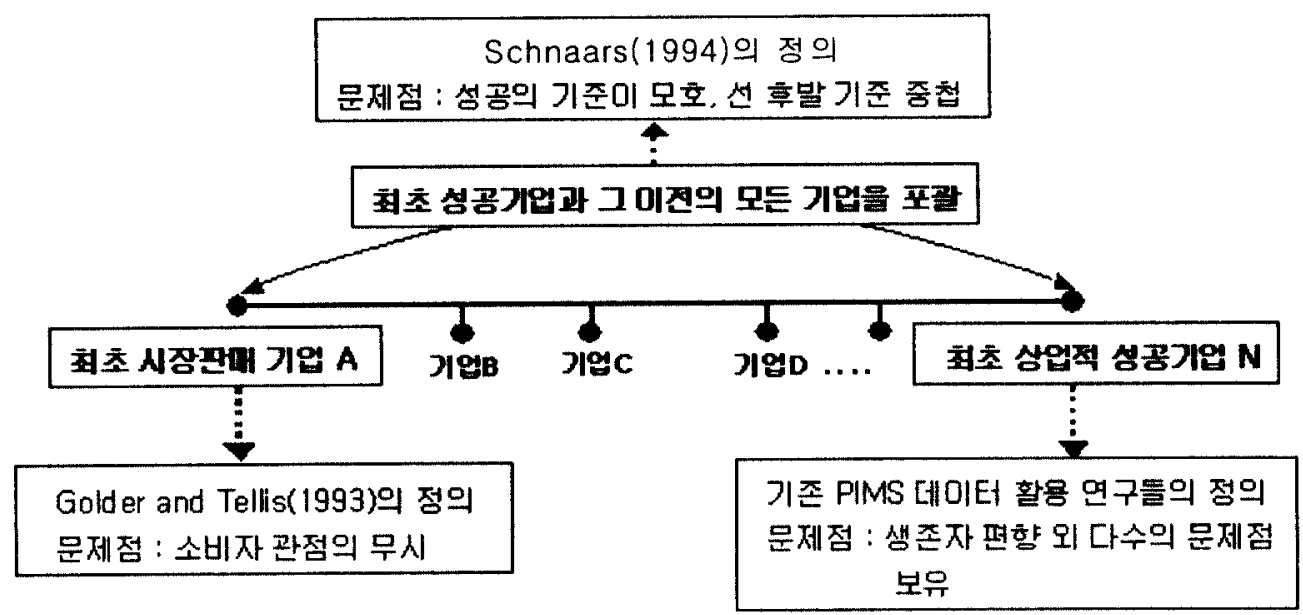

4.2 시장의 정의에 관한 연구 : 기업역량의 전이 가능성과 경쟁의 범위

다음으로 시장 진입순서와 관련된 연구를 할 때 생각해 보아야 할 이슈 중의 하나는 시장 의 정의를 어떻게 내리는가 하는 것이다. 시장의 정의와 관련된 문제는 크게 두 가지로 나 누어서 생각할 수 있는데, 시장개척의 의미를 무엇으로 볼 것인가와 그 경계를 어디에 둘 것인가이다.

선발 진입한다는 것은 기업이 새로운 시장을 개척하는 것을 의미한다. Lieberman과 Montgomery(1988)가 제시한 선발이점의 전략적인 가정은 여러 가지 형태에 해당하는 자원의 선점(preemption)에 기초하는데, 선발진입으로 자원의 선점이 가능하기 위해서는 시장의 개 념이 근본적으로 완전히 새로운 곳이어야 함을 시사하고 있다.

그러나 지금까지의 많은 연구들이 간과하고 있는 사실은 신생기업(start-up firm)으로서, 
처음으로 시장에 진입하는 기업과 다각화의 일환으로 신규 시장에 진입하는 기존기업 (existing firm)과의 명확한 구분이 없이 연구 대상올 혼용하여 왔다는 것이다. 또한 기존 기업이라 할지라도 목표로 하고 있는 신규시장으로 기업의 자원과 역량의 전이가 가능한가 여부에 따라 그 효과가 달라질 수 있는데도 그에 대한 고려가 없거나 부족하다는 것이다(예 외적으로 Mitchell(1991)의 연구가 있다). 만약 특정 기존기업이 자사가 지닌 자원과 역량 의 전이가 가능한 시장으로 선 ·후발 진입하여 높은 시장점유율을 달성하였다면 이는 진입 순서와는 커다란 상관이 없는 과거의 경험, 즉 강력한 브랜드명, 구축된 유통망, 광고기술 과 이를 위해 필요한 자금을 확보하는 능력 둥을 통해 생겨난 결과라 할 수 있다.

다음으로, 시장의 경계를 어디에 두는가 하는 문제는 경쟁의 범위와 관련이 있다. 보통 시장의 경계를 넓혀서 해석하면 경쟁자의 수가 늘어나게 되고 이는 선발 기업의 시장점유율 을 낮추는 결과를 가겨온다. 상대적으로 시장의 경계를 좁개 본 Urban et al.(1986)의 연구 는 평균 경쟁자 수를 4개, 소비재 PIMS 데이터를 중심으로 한 Robinson(1992)은 경쟁자의 수를 12개, Golder and Tellis(1993)는 명확히 기술하고 있지는 않지만 가장 넓은 카테고리 에 기초하여 진입순서의 효과를 분석하였는데, 이들 각 연구들의 선발기업 시장점유율은 각 각 $42 \%, 29 \%, 19 \%$ 로 나타났다. 이러한 결과는 고려하고 있는 시장 범위와 선발기업의 시장 점유율 간에 부정적인 관계가 있음을 추론할 수 있게 한다.

실제로 대부분의 연구들이 상품형태수준의 경쟁 범주에 너무 집착하는 경향을 보임에 따 라(Alpert et al., 1995; Shankar et al., 1998; Urban et al., 1986), 대체가능성이 있는 경쟁제품에 대한 고려가 미흡한 만큼 좀더 시야를 넓혀서 시장을 인식할 필요가 있으며, 이 에 대한 대안으로 경제학에서 사용하고 있는 대체성(substitution)의 개념을 사용하는 것도 하나의 기준이 될 수 있으리라 판단된다. 즉, 단순한 상품형태수준에서의 시장정의에서 탈 피하여 적절한 수준의 대체성을 지닌 제품을 포괄적으로 포함하여 시장을 정의하는 방법인 데, 구체적으로는 어떤 상품을 기준으로 가장 가까운 대체재를 찾고 연속적으로 대체재를 나열하면서 어떤 점에서 대체성의 정도에 중요한 갭이 나타날 때까지 동일시장으로 파악하 는 것을 의미한다(Robinson 1969). 그러나 교차탄력성(cross elasticity)으로 계측될 수 있 는 대체성도 어떤 점에서 시장 또는 산업의 범위를 명확히 구분하느냐는 역시 실증분석의 과제이지 명확한 이론적 기준을 제시할 수는 없는 문제로 제품의 공급지역을 고려한 시장의 지역적 한계, 수요와 공급의 교차탄력성, 기업간의 상호의존성을 고려하여 선택되어져야 하 는 것으로 알려져 있다. 따라서 향후 연구에서는 기업과 시장간의 차이를 명확히 하여 좀더 정확한 진입순서 쵸과를 규명할 필요가 있으며, 경쟁 범위에 대한 통제 및 다양한 접근을 통해 효과 해석에 대한 주의를 높일 필요가 있다.

\section{3 소비자관점에서의 선발이점 발생 원인 규명에 관한 연구}

앞서 소비자행동 관점에서의 선발이점 발생에 관한 기존 연구들을 살펴본 결과, 선천적 선발 이점 발생, 후천적 노력에 의한 선발 이점 발생, 선발이점은 위조된 효과라는 세 가지 관 점의 가설들이 제시되었었다. 물론 그동안 많은 연구들에서 선천적 선발 이점이 나타남을 보여주고 있으나(Kardes and Kalyanaram 1992; Kardes, Kalyanaram, Chandrashekaran, and Dornoff 1993; Carpenter and Nakamoto 1989), Kardes(2002)가 지적하였듯이 경우에 따라서 는 후천적 노력에 의해 선발이점이 나타날 가능성이 충분하기에 앞으로 이 부분에 대해 더 많은 실증적 연구들이 이루어질 필요가 있다. 특히 어떠한 제품군이냐 어떠한 상황이냐에 
따라 선천적 이점보다는 후천적 노력에 의한 선발 이점이 더 강하게 나타남을 보여준다면 의미가 있을 것으로 판단된다. 때로는 선발이점이 선천적으로, 즉 아무런 노력 없이 자동적 으로 생기기보다는 선발기업 나름대로의 독특한 포지셔넝 전략과 광고, 판촉 둥의 커뮤니케 이션 전략, 유통 전략에 의해 나타날 수도 있는 것이다. 선발기업이라 할지라도 선발이라는 상황에 기본적으로 내재되어 있는 선천적 이점들이 나타나도록 하기 위해서는 그 기업 나름 대로의 마케팅 노력, 전략이 선행되어야 함을 보인다면 이전 대다수의 연구와는 또 다른 방 향의 시사점을 제공하리라 생각된다.

또한 경우에 따라서는 선발이점이 순수한 진입순서에 의한 효과라기보다는 선발 진입한 기업이 이미 대규모의 자원과 예산을 가진 강력한 파워를 가진 기업이기에 나타나는 효과인 지를 검증할 필요가 있다. 이러한 위조효과 역시 상황에 따라, 산업 톡성에 따라, 문화적 차이에 따라 나타날 수도 있고 나타나지 않을 수도 있기에 어떠한 경우에 선발이점보다는 위조효과에 의한 것임을 보여주는 것이 중요하다. 가령 우리나라의 경우 순수한 선발이점 효과가 나타나는 경우 보다는 위조효과에 의해 선발이점이 나타나는 경우가 더 많음을 가설 을 세워 검증해 볼 수 있는 것이다. 아무튼 향후 연구에서는 이러한 위조효과 발생 여부와 그러한 효과의 발생 상황에 대한 보다 자세한 실증적 검중이 필요하리라 본다.

4.4 소비자관점에서의 후발이점 발생 및 선발이점 극복 전략에 관한 연구

앞서 후발이점 발생 및 선발이점 극복에 관한 기존 연구들을 살펴보면 소비자관점에서의 연구가 부족하다는 사실을 발견하게 된다. 후발이점 발생의 경우 선발이점 발생과 마찬가지 로 주로 생산자 관점에서 이루어지고 있고, 선발이점 극복 전략 역시 소비자 심리나 행동 관점에서의 접근보다는 거시적 전략 차원의 접근이 주를 이루고 있다. 후발이점 발생이나 이를 이용한 선발자 따라잡기(catch-up) 전략의 경우 좀 더 근본적인 시사점을 얻기 위해서 는 소비자 관점의 접근이 지금보다 더 정교하계 실행될 필요가 있다.

$\operatorname{Kardes}(2002)$ 에 의하면, 코카콜라-펩시콜라 비교처럽 이미 장기기억 내에 태도가 형성되 어 있는 경우의 비교는 태도기반 선호도(attitude based preference) 판단이 된다. 반면 낯 선 제품군이나 브랜드에 대해서는 기형성된 태도가 없기에 이때 소비자는 속성기반 선호도 (attribute based preference)에 의거하여 판단을 내리게 된다. Kardes(2002)는 판단 시 선 호도 기반의 결정은 소비자의 이전태도 형성 여부에 달려있다고 한다. 그리고 Sanbonmatsu, Kardes, and Gibson(1991)은 정보처리목적(information processing goal)에 의해서 선호도 판단 기반이 결정된다고 한다. 즉 전반적 이미지 형성을 하도록 조작할 경우 태도기반 선호 도 판단이 나타나지만, 각 제품 속성에 대해 기억하도록 조작할 경우 속성기반 선호도 판단 이 나타나는 것이다. 그리고 비교적 최근 연구인 Mantel and Kardes(1999) 연구에 의하면 개인별 인지 옥구 정도(need for cognition)에 의해서도 선호도 판단이 달라짐을 보이고 있 다. 인지 옥구가 강한 경우, 즉 생각하는 것을 즐기는 소비자의 경우 속성기반 선호도 판단 이 강하게 나타난다는 것이다.

그런데, 속성기반 선호도 판단 시에는 Kardes(2002), Mantel and Kardes(1999), Sanbonmatsu et al.(1991) 등에 의하면 비교방향성 효과(direction-of-comparison effect) 가 나타난다는 점이 흥미롭다. Sanbonmatsu et al.(1991) 연구에 따르면, 일단 공통 속성 (shared attributes)은 선호 판단에 별 영향을 미치지 못하는 것으로 나타났다. 그리고 첫 번째 소개된 제품의 독톡한 속성(unique attributes)보다는 두 번쩨 소개된 제품의 독특한 
속성이 선호도에 더 큰 영향을 미치는 것으로 나타났다. 이러한 불균형성(asymmetry)을 비 교방향성효과라고 하는데, 두 제품 간 비교에서 고려되는 순서가 선호 판단에 강한 영향을 미치는 현상이다. 이러한 현상이 나타나는 이유는 두 번째 제품의 속성이 제공되기 전까지 는 속성 비교가 일어나지 않는데다, 최근에 소개된 속성이 기억으로부터 더욱 접근적 (accessible)이기에 두 번째 제품의 속성이 더욱 현저해지면서 영향력을 가지게 되기 때문 이다. 결국 두 번째 제품의 속성이 비교의 기준이 되는 것이며, 이러한 비교과정에서 공통 속성의 경우 차별점이 없기에 진단적 정보가 되지 못하며, 두 번째 제품의 독특 속성은 첫 번째 제품에서는 볼 수 없는 속성이기에 주목을 받게 되어 선호 판단에 강한 영향을 미치게 되는 것이다.

이들 실험 결과들이 시사하는 바를 정리해보면, 우선 태도기반 선호 판단이 일어나는 경 우에는 선발이점이 강하게 나타난다고 볼 수 있다. 즉 각 제품 또는 브랜드에 대해 전반적 이미지, 인상을 통해 선호 판단울 하기에 아무리 떠ㅇㅓㅓ나고 독특한 속성을 가진 후발자라 하 더라도 태도기반의 선호 판단 하에서는 함을 쓰기가 어렵게 된다. 반면 선발진입을 통해 강 력한 이미지와 굳건한 태도를 이미 소비자 마음속에 형성시킨 선발자의 경우 별 어려움 없 이 긍정적 선호를 이끌어 낼 수 있는 것이다. 그러나 속성기반 선호 판단이 일어나는 상황 에서는 선발자보다 오히려 후발자가 더 유리한 경우가 충분히 발생할 수 있다고 볼 수 있다. 앞서 실헙에서 살펴보았듯이 시차를 두고 뒤늦게 진입한 제품이 비교의 기준이 되어 이들의 독특한 속성이 차별 포인트가 될 수 있음이 밝혀졌기에, 후발자가 더 유리한 상황이 충분히 예상될 수 있는 것이다. 따라서 비교방향성효과는 후발이점을 이끌어내는 심리적 메커니즘 으로 작용할 수 있음을 예측해 볼 수 있다.

또한 제품군의 특성에 따라, 소비자의 특성에 따라 얼마든지 후발이점을 끌어낼 수 있다 는 시사점을 얻을 수 있게 된다. 예를 들어, 기존에 잘 알려지지 않은 브랜드끼리 경합을 벌이는 시장의 경우 기형성된 태도가 없기 때문에 속성기반의 선호 판단이 일어날 가능성이 크다고 할 수 있다. 이 경우 먼저 진입한 선발자에 의한 선발이점보다는 뒤늦게 진입한 후 발자에 의한 후발 이점 발생 가능성이 더 높다고 할 수 있으며, 이는 앞서 살펴보았듯이 비 교방향성효과에 의한 것으로 예측할 수 있을 것이다. 반면 조금이라도 알려진 브랜드들이 포함된 시장에서의 경쟁일 경우 속성기반 선호 판단보다는 태도기반 선호 판단이 일어날 가 능성이 높으며, 따라서 선발이점이 나타날 가능성이 높다고 예측할 수 있게 된다. 한편 이 미 알려진 브랜드들끼리 경합을 벌이는 새로운 제품 카테고리에서도 소비자들로 하여금 태 도기반 선호보다는 속성기반 선호 판단을 하도록 유도한다면 후발이점을 발생시킬 가능성이 나타나게 된다. 족 정보처리 목적이나 인지필요성을 개별 속성에 대한 정교한 인지적 처리 방향으로 이끌게 되면 속성기반 선호 판단을 통해 비교방향성에 의한 후발이점 발생 가능성 을 높이게 되는 것이다.

아울러 후발이점 역시 앞서 선발이점 발생에 관한 3 가지 가설과 같은 논리로 3 가지 가설 을 세워보고 어느 가설이 어느 상황에서 좀 더 잘 나타나고 타당한지를 검증해 불 수 있을 것이다. 우선 선천적 후발이점 발생의 경우, 제품군의 특성이나 소비 상황의 특성으로 인해 후발이점이 자동적으로 발생할 가능성이 존재할 수 있을 것이다. 후천적 노력에 의한 후발 이점 발생의 경우, 대부분의 후발이점 발생이 여기에 해당될 것으로 예상되는데, 자동적으 로 후발이점이 발생하기보다는 비교가능 속성에서의 차별화, 속성중심 선호 판단으로의 유 도, 비교방향성 효과 발생으로의 유도 등을 통해 나타날 수 있을 것이다. 위조된 후발이점 발생의 경우 순서에 의한 후발이점 발생이기보다는 기업 크기나 파워, 마케팅 예산 규모에 
의해 나타나는 경우라고 할 수 있으며, 우리나라의 경우 대기업이 막강한 브랜드 파워나 마 케팅 예산력을 가지고 미투(me-too)제품을 출시하여 선발 중소기업에 의해 개척된 시장을 잠식하는 경우를 예로 들 수 있을 것이다.

\section{5 진입순서 효과에 영향을 미치는 수요자측면의 조절변수에 관한 연구}

기존 연구에서 진입순서의 효과를 조절하는 변수들에 대한 고려는 주로 생산자 관점에서 다루어져 았다(Lamskin 1988; Kerin, Varadarajan, and Peterson 1992; Szymanski, Troy, and Bharadwaj 1995; 이문성과 최이규 2002), 이는 제품을 소비하는 소비자 입장에서 선발 진입이 지니는 의미가 무엇인가를 분석하기보다 산업특성, 경쟁특성, 기업특성, 전략톡성과 같이 제품을 제공하는 기업의 입장에 연구의 초점이 맞추어져 진행 되어왔음을 의미한다. 그러나 혁신적인 제품이나 정보재의 경우, 특히 수요자 측면의 규모의 경제라 할 수 있는 네트워크의 외부성(network externality)이 존재하는 제품은 선발진입의 성공여부가 그젓을 수용하는 수요자의 특성에 따라 달라질 수 있음에도 불구하고 마케팅 분야에서의 실증적인 연구는 거의 이루어지지 않았다. 이에 본 절에서는 진입순서 효과에 영향을 미치는 수요자 측면의 조절변수로 (1) 표준에 대한 기대. (2) 소비자의 이질성, (3) 소비자의 혁신성향, (4) 지식의 전문성 등을 제시하고자 한다.

네트워크 효과(network effect), 멧칼프(Metcalfe)의 법칙 둥으로 다양하게 불리는 네트 워크 외부성이란 한 사람이 보유하고 있는 제품의 가치가 다른 사람이 그 제품을 얼마만큼 보유하고 있는가에 의해 결정되는 것을 의미한다(Shapiro and Varian 1999). 이렇게 제품의 가치가 사용자 수의 증가에 비례하는 네트워크 효과를 보이는 경우 수확체중의 법칙이 적용 된다(Arther 1996). 즉 소비자 측면의 규모의 경제인 네트워크의 외부성이 존재하는 시장에 서는 일단 초기에 시장 주도권을 확보한 기업이 지속적인 경쟁력을 가지고 그 영향력을 확 대해 나갈 수 있는 유리한 위치를 점하게 된다. 이는 기존 사용자 기반이 소비자의 효용에 긍정적 영향을 미침을 의미하고(Brynjolfsson and Kemerer 1996), 결과적으로 후발주자의 경우 그만큼의 기회률 상실함을 의미한다. 따라서 네트워크의 외부성이 존재하는 경우 선발 진입 기업은 시장의 선점(critical mass의 확보)을 통해 그 효과를 증대시킬 수 있는 반면, 후발기업은 상대적으로 적은 네트워크의 크기와 기존 소비자들의 높은 전환비용으로 인해 불리한 위치에 놓이게 된다. 이 경우, 어떠한 신기술이나 신제품이 출시되었을 매 이것이 시장의 표준으로 자리잡을 것이라는 소비자의 기대는 선발기업의 효과를 높일 수 있다. 사 람들은 보통 제품을 선텍할 때 가격이나 품질 이외에 향후에 이 제품이 시장에서 주류로 여 겨질 것 인가에도 관심을 가지게 되는데, 모든 조건이 유사하다면 앞으로 시장에서 인기를 끌 것이라든지, 표준으로 자리잡울 것이라 예상되는 제품을 구매하는 경향이 있다(Choi 1994; Farrell and Saloner 1985). 예를 들어, 소비자들은 가입자 수가 많은 통신서비스에 가입하려 할 것이고 시장에서 주류를 이룰 것이라 예상되는 운영체계를 선택하려 할 것이다. 여기에서 네트워크의 외부성과 관련하여 주목해야 할 점은 소비자의 선택은 다른 소비자들 의 선택행위에 영향을 받으며, 역으로 자신들의 선택행위가 다른 소비자들의 선택에 영향을 미친다는 것이다. 따라서 혁신적인 신제품으로 선발 진입하는 기업이 여러 가지 커뮤니케이 션 전략을 통해 자사제품에 대한 표준으로서의 기대를 중대시킬 수 있다면, 결과적으로 소 비자들의 구매에 대한 불확실성을 감소시켜 선발진입의 긍정적인 효과를 기대해 볼 수 있다.

소비자의 이질성(Consumer Heterogeneity)은 한 시장내의 소비자의 욕구가 다양하고, 제 
품에 대한 평가가 이질적임을 의미한다(Shapiro and varian 1998). Shapiro and Varian (1998)은 수요측면에서의 시장구조가 정(positive)의 피드백 효과에 기초하고 있는가를 설 명하는 갓대로 규모의 경제와 소비자 욕구의 다양성을 들고 있다. 규모의 경제가 크게 나타 나는 산업에서는 정의 피드백 효과가 나타나게 될 가능성이 큰 반면, 소비자의 욕구가 다양 하게 나타나는 산업에서는 정의 피드백 효과가 나타날 가능성이 적다고 지적한다. 즉 소비 자의 기호가 서로 상이하면 하나의 표준이 산업을 지배하는 것이 어려워지고 특정 신제품이 크게 성공하거나 크게 실패할 가능성이 적어지게 된다(Katz and Shapiro 1986). 결과적으로 새로운 제품을 가지고 선발 진입한 기업이라 할지라도 목표로 하는 시장의 소비자 욕구가 상이하면, 초기에 규모의 경제 달성을 통한 효율적인 진입장벽의 구축이 어려워 선발진입을 통한 성과는 부정적인 영향을 받을 수밖에 없을 것이다.

더불어 혁신적인 성향을 지닌 소비자는 기술의 변화에 민감하고 제품의 실제 효용보다는 기술자체에 높은 관심을 보인다(Moore 1991). 목표로 하고 있는 소비자 집단이 혁신적 성향 이 강하다면, 혁신적 제품의 출시에 보다 적극적으로 반응할 가능성이 크고, 결과적으로 혁 신기업은 선발진입으로 인해 보다 높은 성과를 향유할 수 있다. 반면, 신기술 수옹에 소극 적인 소비자들은 최종 결정을 하고도 제품의 구매를 미루거나, 제품이 완벽한 표준으로서 자리잡을 때까지 기다리는 습성이 있다. 이러한 목표시장에 혁신적 제품으로 진입하는 기업 은 선발진입으로 인한 이점보다 고객의 불확실성으로 인한 불이익올 경험할 가능성이 크기 때문에 결과적으로 높은 성과를 기대하기 힘들다.

한편, 소비자들은 후발진입 브랜드의 품질에 대해 부정확한 정보를 가지고 있을 때, 만족 스러웠던 첫 번째 브랜드를 고수하려는 경향이 있다(Schmalensee 1982). 여기에서 주목할 것은 선발진입의 효과는 소비자들의 불완전한 정보에 의해 조절된다는 것이다. 즉 시장에 출시된 제품들에 대한 지식이 부족한 경우 소비자들은 이에 따른 심리적인 부담을 해소하기 위해 선발제품을 지속적으로 재구매를 한다는 것이다. 이는 역으로 보면 소비자들이 제품에 대한 전문적인 지식을 가지고 있는 경우 선발진입의 효과는 달라질 수 있음을 시사한다. 특 히, 인터넷의 발달로 인한 판매자와 구매자간 정보 불균형의 해소는 전반적인 소비자의 제 품지식을 끌어올리는 역할을 할 것으로 보이며 결과적으로 이는 진입순서 효과에 영향을 미 칠 것이라 예측할 수 있다.

\section{6 시장 진입순서 결정의 선행변수에 관한 연구}

기존의 연구들은 시장 진입순서를 결정하는 선행변수로서 기업내부의 자원에 근거한 특 성과 시장 및 경쟁특성을 주로 언급하였다. 그러나 기업의 전략적인 의사결정을 보다 심충 적으로 이해하기 위해서는 조직특성에 대한 고려가 중요하게 인식되고 있다(Frambach 1993; Rogers 1983). 본 연구에서는 시장 진입순서 결정에 영향을 미치는 조직특성 변수로서 (1) 조직의 관료화, (2) 조직의 혁신성, (3) 조직학습의 유형 둥을 언급하고자 한다.

먼저, 조직의 관료화는 기업의 의사결정 속도를 늦추고 환경변화에 대한 유연성을 떨어뜨 림으로써 시장진입을 늦추는 역할을 할 것이라 제안해 볼 수 있다(Haveman 1993). 특히 선 행변수에 대한 기존 연구들이 기업규모를 가용자원의 대리변수로 보는가(Fuentelsaz et al. 2002) 또는 관료주의의 대리변수로 보는가(Schoenecker 1998)에 따라 다른 결과를 도출하였 기 때문에, 조직의 관료화나 공식화와 같은 조직특성 변수의 직접적인 영향력을 고려해 봄 으로써 논란을 불식시킬 필요가 있다고 보여진다. 
다음은 조직의 혁신성으로, 이는 기업의 진입순서 결정에 정(+)의 영향을 미칠 것이라 예 상할 수 있다. Deshpande, Farley, and Webster(1993)는 특정 기업의 혁신정도가 높을수록 환경변화에 대응하여 사업전략이나 구조를 변경하는데 적극적인 성향을 보인다 하였다. 진 입순서 결정에 있어서도 적극적인 성향을 보일 것이며, 따라서 조직의 혁신성이 높을수록 선발진입에 대한 의지가 강할 것으로 예측할 수 있올 것이다.

마지막으로, March(1991)에 따르면 조직의 학습 유형은 크게 '새로운 것에 대한 탐험' 과 '기존 지식의 활용' 으로 나누어지는데, 기업은 보유 자원의 한정으로 인하여 이들 두 유형간의 균형보다는 어느 한쪽에 치우치는 선택을 하게 된다고 한다(March, 1991; Winter, 1971). 이때 탐험적 성향이 강한 조직일수록 혁신을 추구하고 위험을 감수하는 행위를 많이 하지만, 활용적 성향이 강한 조직은 기존 지식을 통해 안정적이고 효율적인 할동을 추구할 가능성이 높아진다. 따라서 시장 진입순서 결정에 있어서도 이러한 조직 학습의 성향에 따 라 기업마다 다른 의사결정이 나타날 것으로 예상할 수 있다.

\section{7 진입시차 효과의 조절 역할에 관한 연구}

선발이점에 중요한 영향을 미치는 요인 중에 선발기업과 후발기업 간의 진입시차가 있는 데(Kerin, Varadarajan, and Peterson 1992), Brown and Lattin(1994)과 Huff and Robinson(1994)은 실제로 실중분석을 통하여 후발브랜드의 시장진입이 늦어질수록 선발브랜 드의 시장점유율이 높아짐을 보여주고 있다. 구체적으로 Robinson and $\operatorname{Min}(2002)$ 은 진입시 차와 후발기업의 생존율은 역U자형을 보임을 실중하였다. 족 바른 후발진입은 시장과 기술 의 불확실성 감소에 따른 이점을 향유하여 선발진입보다 더 높은 생존율을 보일 수 있지만, 시간이 경과하게 되면 선발기업의 이점이 보다 막강해지기 때문에 후발기업의 생존율은 감 소한다고 하였다.

물론 후발기업의 진입이 늦어질수록 선발이점이 커지는 상황이 많이 나타나겠지만, 역으 로 후발기업의 진입이 따를수록 오히려 선발기업에게 도움이 되는 경우가 나타날 수도 있다. 혁신적인 제품, 흭기적인 재품과 같이 신제품이 대단히 이례적일 경우 제품에 대한 소비자 인식상의 수용이나 학습이 어려워 초기 시장 형성이 쉅지 않을 것이며. 이 경우 아무리 선 발기업이라 할지라도 시장 형성이 미약하여 선발이점이 제대로 나타나지 않을 수도 있다. 이럴 때는 오히려 후발기업의 진입이 빠를수록 해당 시장에 대한 관심 학대와 함께 소비자 의 시장에 대한 인지도가 높아질 것이며, 이로 인해 Kardes and Kalynaram(1992)가 보여주 었둣이 후발자와 비교해 선발자가 더욱 새롭고 흥미로워 보이는 집합크기효과(set-size effect)가 발생해 선발이점이 강해질 수 있는 것이다. 한편 Carpenter \& Nakamoto(1989)는 선발 기업과 유사한 특성을 가진 후발 기업들이 계속 진입해 들어올 경우 이들은 하나의 그 릅으로 범주화(categorization)가 되어 소비자들에게 새로운 제품군에 대한 인식을 확고하 게 해주며, 일종의 유인효과(attraction effects)가 발생하여 선발기업은 해당 제품군의 전 형적인 브랜드로 인식되어 질 수 있다고 하였다. 후발기업의 조기 진입이 선발기업에게 도 움이 될 수 있다는 것올 추론할 수 있게 한다.

또한 후발기업이 선발이점을 극복하는 방안의 하나로서 진입시차가 제시되고 있는데(전인 수와 김주환 2001), 여기에서도 산업 또는 제품의 특성이 조절변수의 역할을 할 수 있올 것 으로 예상할 수 있다. 즉 생활용품과 같은 범용품은 후발기업이 딸리 진입하여 선발기업의 진입장벽 효과가 나타나는 것을 조기에 차단하는 것이 효과적이나, 혁신품이나 아이디어 성 
향이 강한 제품의 경우 딸리 진입하게 되면 오히려 선발기업의 미끼가 되어 선발기업을 해 당 제품군에서 더욱 전형적인 것으로 부각시키는 현상을 초래할 수 있다. 따라서 향후 연구 에서는 이 부분에 대한 면밀한 검중이 필요하리라 본다. 결론적으로, 선발기업과 후발기업 간의 진입시차가 기업의 성과에 미치는 영향을 파악하는 데에는 그 영향력을 조절해주는 변 수가 무엇인지 파악하는 연구가 필요할 것으로 판단된다.

\section{5. 맺음말}

본 연구는 지금까지 학계에서 꾸준히 연구되고 있는 시장 진입순서 분야에 관한 문헌고찰 을 통해 통합적인 시각을 제시하고, 기존 연구의 한계점을 바탕으로 보다 나은 이해를 이끌 어낼 수 있는 향후 연구방향을 제시하였다. 본 연구는 기존의 연구를 크게 선발이점 발생에 관한 연구, 후발이점 발생에 관한 연구, 진입순서 효과에 영향을 미치는 조절변수에 관한 연구, 진입순서 의사결정에 영향을 미치는 선행변수에 관한 연구 둥으로 구분하고 통합적인 틀을 제시, 각 연구 분야에 대한 한계점 지적과 향후 연구방향을 제시하였다.

본고의 서두에서도 언급한 바와 같이 시장 진입순서와 관련된 초기의 연구들은 진입순서 효과에 대한 시장 결정론적 시각을 보여온 반면, 보다 최근에 이루어진 연구들은 이러한 고 정된 시각에서 탈피하여 진입순서가 기업의 성과에 영향을 미치게 되는 내-외부적인 메커 니즘과 그 원인에 대한 규명 둥 다양하고 적극적인 연구 시도를 하고 있다. 그러나 이러한 진입순서에 관한 연구는 그 끓임없는 관심에도 불구하고 선 - 후발 진입에 대한 정의와 기업 이 속해있는 시장에 대한 정의가 불분명하게 이루어짐에 따라 그 효과도 매우 다르게 나타 나는 것이 사실이다. 따라서 향후 연구에서는 이에 대한 심층적인 접근이 필요하다고 보여 진다. 더불어 진입순서효과에 대한 메커니즘 연구도 사후적인 해석이 아닌 실증적인 규명을 통해 이루어져야 할 필요성이 있다.

진입순서 효과에 영향을 미치는 조절변수에 대한 연구는 거의 대부분 생산자 관점에서 이 루어져 왔음을 알 수 있다. 그러나 혁신적인 제품이나 정보재, 특히 수요자 측면의 규모의 경제라 할 수 있는 네트워크의 외부성(network externality)이 존재하는 제품은 선발진입의 성공여부가 그것을 수용하는 수요자의 특성에 따라 달라질 수 있음에도 불구하고 이 부분에 대한 고려는 활발하게 이루어지지 않았다. 이에 본 연구에서는 소비자 관점에서 진입순서 효과에 영향을 미치는 조절변수를 제시하였다.

다음으로 진입순서 의사결정에 영향을 미치는 선행변수에 관한 기존 연구는 크게 자원기 반관점에 따른 요인, 시장-경쟁요인 등을 중심으로 이루어져 왔다. 그러나 본 연구에서는 이와 더불어 기업의 전략적인 의사결정을 보다 심층적으로 이해하기 위해서는 조직 내부 특 성에 대한 다양한 고려가 필요함을 인식하고 각각에 해당하는 구체적인 선행 변수들을 제시 하였다. 마지막으로 본 연구에서는 진입순서 외에도 후발기업의 진입시차에 대한 추가적 연 구의 필요성을 언급하고 조절 역할 변수 등을 제시하였다.

저자들은 본 연구에서 제시한 통합적 연구 틀과 향후 연구 방향을 중심으로 새로운 실증 연구가 많이 이루어지길 바라며, 그 동안 많은 논란이 되어왔던 진입순서 효과에 관해 새로 운 시사점들이 도출되기를 기대해 본다. 


\section{<참고문헌>}

손용석, 김용준, 임양환 (2001), “후발진입 인터녯 사이트의 차별화 전략에 관한 연구,"

마케팅연구, 16(3), 21-43.

이문성, 최이규 (2002), “후발기업의 모방전략, 환경특성 및 경영성과의 상호관련성 연

구," 경 영학연구, 31(2), 405-429

이윤철, 이동현 (1999), “첨단 기술산업에서 후발기업의 Catch-up 전략에 관한 연구," 전

략경영연구, 23-46

(1998), “후발기업의 전략에 관한 개념적 모델," 춘계학술연구 발표회,

한국경영학회, 403-406.

전인수, 김주환 (2001), “선발이점 극복을 위한 후발제품의 마케팅전략에 관한 연구," 경

영학연구, 30(3), 745-763

최진아 (2000), "e-Business에서의 진입순서효과: 후발기업은 기능성을 가지는가?" 2000

년도 동계학술연구 발표희, 한국경영학희, 131-145.

하영원, 서찬주 (1999), “후발진입상표가 시장개척상표를 앞지르는데 있어 광고의 역할에 관한 탐색적 연구,” 광고학 연구, $10(2), 9-38$.

Alpert, Frank H. and Michael A. Kamins (1995), "An Empirical Investigation of

Consumer Memory, Attitude, and Perceptions Toward Pioneer and Follower Brands," Journal of Marketing, 59(October), 34-45.

and John L, Graham (1992), “An Examination

of Reseller Buyer Attitudes Toward Order of Brand Entry," Journal of Marketing,

56(July), 25-37.

Anderson, P., and Tushman, M. L. (1990), "Technological Discontinuities and

Dominant Designs: A Cyclical Model of Technological Change," Administrative Science Quarterly, 35(4), 604-633.

Arthur, Brian (1996), "Increasing Returns and New World of Business," Harvard Business Review, July-August, 100-109.

Bain, Joe S. (1956), Barriers to New Competition, Cambridge, MA: Harvard University Press, P.216

Berndt, E. R., L. Bui, D. Deley, and G. L. Urban (1995), "Information Market ing and Pricing the U. S. Anti-ulcer Drug Market," American Economic Review, 85(2), 100-105.

Bond, R. S. and Lean, D. F. (1977). "Sales, Promotion, and Product Differentiation in Two Prescription Drug Markets," Staff Report to the U.S. Federal Trade Commission, Washington. and (1979), "Consumer Preference, Advertising, and Sales: on the Advantage from Early Entry," Working Paper 14, Bureau of Economics, U.S. Federal Trade Commission. Washington, October.

Bowman, D. and H. Gatignon (1996), "Order of Entry as a Moderator of the Effect of Market ing Mix on Market Share." Marketing Science, 15(3), 222-42.

Brown, Christina L, and James M. Lattin (1994), "Investigating the Relationship 
Between Time in Market and Pioneering Advantage," Management Science, 40 (October), 1361-69.

Brynjolfsson, E., and Kemerer, C. F. (1996), “Network Externalities in Microcomputer Software: An Econometric Analysis," Management Science, 42(7), 32-46. Buzzell, Robert D. and Bradley T. Gale (1987), The PIMS Principles: Linking Strategy to Performance. New York: The Free Press.

Carpenter, G. S. and Lakshman Krishnamurthi (1998), "Late Mover Advantage: How Innovative late entrants outsell pioneers," Journal of Marketing Research, Vol. 35(1), 54-70.

D. R Lehmann, K. Nakamoto, and S. Walchli(1997), “Pioneering Disadvantage: Consumer Response to Differentiated Entry and Defensive Imitation," Working Paper, Northwestern University.

and K. Nakamoto (1989), "Consumer Preference Formation and Pioneer ing Advantage," Journal of Marketing Research, 26 (August), 285-98. and (1990), "Competitive Strategies for Late Entry Into a Market

With a Dominant Brand," Management Science, 36 (0ctober), 1268-78. and M. Sawhney (1996), "Multi-Generation New Product Strategy: The Role of

Consumer Learning in Evolving Markets," Working Paper, Marketing Department, Nor thwestern University.

Choi, J.P. (1994), “Irreversible Choice of Uncertain Technologies with Network Externalities," Rand Journal of Economics, 25(3), 382-401.

Cooper, Robert G. (1979), "The Dimensions of Industrial New Product Successes and Failure," Journal of Marketing, 43 (Summer), 93-103.

Day, George S. (1984), Strategic Market Planning: The Pursuit of Competitive Advantage. St. Paul. MN: West Publishing Co. and Jonathan S. Freeman (1990), "Burnout or Fadeout: The Risks of Early Entry into High Technology Markets," in Strategic Management in High Technology Firms, Michael W. Lawless and Luis R. Gomez-Mejia, eds. Greenwich, CT: JAI Press, Inc., 43-65.

Farrell, J. and Saloner, G. (1985), “ Standardization, Compatibility, and Innovation," Rand Journal of Economics, 16(1), 70-83.

Fershtman, Chaim, Vi jay Mahajan, and Eitan Muller (1990), Market Share Pioneer ing Advantage: A Theoret ical Approach," Management Science, 36 (August), 900-18.

Flaherty, M. Therese (1983), "Market Share, Technology Leadership, and Competition in International Semiconductor Markets," in Research on Technological Innovation, Management and Policy, R. Rosenbloom, ed. Greenwich, CT: JAI Press, Inc. , 69-102.

Fornell, C. (1985), "Sources of Market Pioneer Advantages in Consumer Goods Industries," Journal of Market ing Research, 22 (August), 305-17.

Fuentelsaz, Lucio, Jaime Gomez, and Yolanda Polo (2002), "Followers' Entry Timing: Evidence From the Spanish Banking Sector After Deregulation," 
Strategic Management Journal, 23(5), 245-264.

Gandal, N. (1994), "Hedonic Price Indexes for Spreadsheets and An Empirical Test for Network Externalities," Rand Journal of Economics, 25(1), 160-170.

Glazer, A. (985), "The Advantages of Being First," American Economic Review, 75 (June), 473-80.

Golder, P. and G. Tellis (1993), "Pioneering Advantage: Marketing Logic or Market ing Legend," Journal of Market ing Research, 30 (May), 158-70

Green, Donna H., Donald W. Barclay, and Adrian B. Ryans(1995), "Entry Strategy and Long-Term Performance: Conceptualization and Empirical Examination," Journal of Market ing, 59(October), 1-16

Guasch, J. L. and A. Weiss(1980), “Adverse Selection of Markets and the Advantages of Being Late," Quarterly Journal of Economics, 94(May), 453-66.

Han, Jin K, Namwoon Kim, and Hong-Bumm Kim (2002), "Entry Barriers: A Dull-, One-, or Two-Edged Sword for Incumbents? Unraveling the Paradox from a Cont ingency Perspective," Journal of Marketing, 65(1), 1-14.

Hauser and Birger Wernerfelt (1990), "An Evaluation Cost Model of Consideration sets," Journal of Consumer Research, 19 (March), 393-408.

Henderson, R. and K. Clark (1990), "Architectural Innovation: The Reconfiguration of Existing Product Technologies and the Failure of Established Firms," Administrative Science Quarterly, 35, 9-30.

Huff, L. C. and W. T. Robinson (1994), "The Impact of Lead Time and Years of Competitive Rivalry or Pioneer Market Share Advantage," Management Science, $40(10), 1370-1377$.

Kalyanaram, G. and G. L. Urban (1992), "Dynamic Effect of the Order of Entry on Market Share, Trial Penetration, and Repeat Purchases for Frequently Purchased Consumer Goods," Marketing Science, 11(Summer), 235-250.

W. T Robinson, and G. L. Urban (1995), "Order of Market Entry:

Established Empirical Generalizations, Emerging Empirical Generalizations, and Future Research," Marketing Science, 14 (3, Part 2), 212-221.

Kardes, F. R. (2002), Consumer Behavior and Managerial Decision Making, NJ: Prentice Hall.

and Gurumurthy Kalyanaram. (1992), “Order-of-Entry Effects on

Consumer Memory and Judgement: An Information Integration Perspective," Journal of Marketing Research, 29(August), 343-357.

. Murali Chandrashekaran, and Ronald J. Dornoff (1993),

"Brand Retrieval, Consideration Set Composition, Consumer Choice, and the Pioneering Advantage, "Journal of Consumer Research, 20, 62-75.

Kaz, M. L. and Shapiro, C. (1986), "Technology adoption in the Presence of Network Externalities," Journal of Political Economy, 94(4), 822-841.

Kerin, Roger A., P. Rajan Varadarajan, and Robert A. Peterson (1992), "FirstMover Advantage: A Synthesis, Conceptual Framework, and Research 
Propositions", Journal of Marketing, 56(October), 33-52.

Lamkin, Mary (1988), “Order of Entry and Performance in New Markets," Strategic Management Journal, 9 (Summer), 127-40.

and George S. Day (1989), "Evolutionary Processes in Competitive Markets:

Beyond the Product Life Cycle," Journal of Marketing, 53 (July), 4-20.

Lane, W. S. (1980), “Product Differentiation in a Market With Endogenous Sequential Entry," Bell Journal of Economics, 11 (Spring), 237-60.

Lieberman, M. B. (1989), "The Learning Curve, Technological Barriers to Entry and Competitive Survival in the Chemical Processing Industries," Strategic Management Journal, 9(Summer), 431-47.

and D. B. Montgomery(1988), “First-Mover Advantages,"

Strategic Management Journal, 19 (Summer), 41-58. and (1998) "First-Mover (Dis)Advantages: Retrospective and Link

with the Resource-Based View," Strategic Management Journal, 19(12), 1111-25.

Lilien, G. L. and E. Yoon (1990), “The Timing of Competitive Market Entry: An Exploratory Study of New Industrial Products," Management Science, 36(5), 568-85.

Makadok, Richard (1998), “Can First-Mover and Early-Mover Advantages be Sustained in An Industry with Low Barriers to Entry/ Imitation?," Strategic Management Journal, 19(7), 683-696.

Mantel, S.P. and Frank R. Kardes(1999), "The Role of Direction of Comparison, At tribute-Based Processing, and Attitude-Based Processing in Consumer Preference," Journal of Consumer Research, 25(4), 335-352.

Markides, Constantinos (1997), "Strategic Innovation," Sloan Management Review, 38(Spring), 9-23.

(1998), "Strategic Innovation in Established Companies," Sloan Management Review, 39(Spring), 31-42.

Miller, Alex, William B. Gartner, and Robert Wilson (1989), “Entry order, Market Share, and Competitive Advantage: A Study of Their Relationships in New Corporate Ventures," Journal of Business Venturing, 4 (May), 197-209.

Mitchell, W. (1989), "Whether and When? Probability and Timing of Incumbents' Entry into Emerging Industrial Subfields," Administrative Science Quarterly, 34, 208-230. (1991), "Dual Clocks: Entry Order Inf luences on Incumbent and Newcomer Market Share and Survival When Specialized Assets Retain Their Value," Strategic Management Journal, 12(January-February), 85-100.

Montaguti, Elisa, Sabine Kuesterm, Thomas S. Robertson (2002), "Entry Strategy for Radical Product Innovations: A Conceptual Model and Propositional Inventory," International Journal of Research in Marketing, 19, 21-42

Moore, Michael J., William Boulding, and Ronald C. Goodstein (1991), "Pioneering and Market Share: Is Entry Time Endogenous and Does in Matter?," Journal of Marketing Research, 28(February), 97-104.

Moore, Geoffrey, A. (1991), Crossing the Chasm, Harper Business, New York, NY 
Parry, Mark and Frank M. Bass (1990), "When to Lead or Follow? It Depends," Marketing Letters, 1 (November), 187-98.

Peterson, Robert A. (1982), Implications of the FCC headstart Policy. Testimony Before the Federal Communicat ion Commission (December).

Porter, Michael (1980), Competitive strategy, New York: The Free Press. (1985), Competitive Advantage. New York: The Free Press.

Prescott, W. and M. Visscher (1977), "Sequential Location Among Firms with Foresight," Bell Journal of Economics, 8, 378-393.

Rangan, Subramanian and Ron Adner (2001), "Profit and the internet: Seven Misconception," MIT Sloan Management Review, 40(Summer), 44-53.

Robinson, J. (1969), The Economics of Imperfect Competition, 2nd ed. St. Mart in Press. Robinson, W. T. (1988), “Sources of Market Pioneer Advantages: The Case of Industrial Goods Industries," Journal of Marketing Research, 25 (1), 87-94. and C. Fornell (1985), "Sources of Market Pioneer Advantages in Consumer Goods Industries," Journal of Marketing Research, 22(August), 305-317. and M. W. Sullivan (1992), "Are Market Pioneers Intrinsically

Stronger than Later Entrants?," Strategic Management Journal, 13(November), 609624.

K. Gurumurthy and G. L. Urban (1994), "First-Mover Advantages from Pioneering New Markets: A Survey of Empirical Evidence," Review of Industrial Organization, 9(February), 1-23.

and Sungwook Kim (2002), "Is the First to Market the First to Fail?

Empirical Evidence for Industrial Goods Businesses," Journal of Marketing Research, 39(February), 120-128.

Sanbonmatsu, D. M., Kardes, F. R., and Gibson D. B. (1991), "The Role of Attribute

Knowledge and Overall Evaluations in Comparative Judgment," Organizational Behavior and Human Decision Processes, 48, 131-146.

Scherer, F. M. and D. Ross (1982), Industrial Market Structure and Economic Performance, (Third Ed., ) Boston: Houghton Mifflin.

Schmalensee, Richard (1982), "Product Differentiation Advantages of Pioneering Brands," American Economic Review, 72 (June), 349-65.

Schnaars, S. P. (1994), "When Entering Growth Markets, Are Pioneers Better Than Poachers?" Business Horizons, 29(March-Apri1), 27-36. (1994), Managing Imitation Strategies: How Later Entrants Seize Market Shares from Pioneers. New York: The Free Press.

Schoenecker, Timothy and Arnold C. Cooper (1998), "The Role of Firm Resources and Organizational Attributes in Determining Entry Timing: A Cross-Industry Study," Strategic Management Journal, 19, 1127-1143

Shanker, Venkatesh, Gregory S. Carpenter, and Lakshman Krishnamurthi (1998), "Late Mover Advantage: How Innovative Late Entrants Outsell Pioneers," Journal of Marketing Research, 35(February), p.54-70. 
(1999), “The Advantages of Entry in

the Growth Stage of the Product Life Cycle: An Empirical Analysis," JournaI of Marketing Research, Vol.34(May), 269-276.

Shapiro, Carl and Hal R. Varian (1999), Information Rules, HBS Press, Boston, MA.

Spiral, Francis C. (1983), “Gaining Market Share Advantage in the Semiconductor Industry by Lead Time in Innovation," In Research on Technological Innovation, Management and Policy, R. Rosenbloom, ed. Greenwich, CT: JAI Press, Inc., 55-67.

Srinivasan, Kannan (1988), "Pioneering Versus Early Following in New Product Markets," Unpublished PhD Dissertation, University of California, Los Angeles.

Sullivan, M. W. (1991), "Brand Extension and Order of Entry," Marketing Science Institute Working Paper, Report Number 91-105. Boston: Market ing Science Institute. (1992), "The Effect of Brand Extension and Other Entry Decision on Survival Time," Horking Paper, Graduate School of Business, University of Chicago. Szymanski, David M., Lisa C. Troy, and Sundar G. Bharadwaj (1995), "Order of Entry and Business Performance: An Empirical Synthesis and Reexamination," Journal of Marketing, 59(October), 17-33.

Tellis, Gerald J. and Peter N. Golder (1996), "First to Market, First to fail? Real Causes of Enduring Market Leadership," Sloan Management Review, 37(Winter), 65-75. Thomas, L. (1996), “Brand Capital and Entry Order," Journal of Economics and Management Strategy, 5, 107-129.

Urban, G. L., T. Carter, S. Gaskin, and Z. Mucha (1986), "Market Share Rewards to Pioneering Brands: An Empirical Analysis of Strategic Implications," Management Science, 32 (June), 645-59.

Vanderwerf, P. and J. F. Mahon (1997), "Meta-Analysis of the Impact of Research Methods on Finding of First-Mover Advantages," Management Science, 43(11), 15101519.

Von Hippel, Eric (1984), “Appropriability of Innovation Benefit as a Predictor of the Functional Locus of Innovation," Horking Paper, 1084-79, Massachusetts Institute of Technology.

White, A. P. (1983), The Dominant Firm: A Study of Narket Power, Ann Arbor, MI:UMI Research Press.

Whitten, Ira T. (1979), "Brand Performance in the Cigarette Industry and the Advantages of Early Entry," Staff Report to the U. S. Federal Trade Commission, Washington.

Yip, George S. (1982), Barriers to Entry. Lexington, MA: Lexington Books/D.C. Health and Company.

Zahra, S., S. Nash and D. Bickford (1995), "Transforming Technological Pioneering into Compet it ive Advantage," Academy of Management Executive, 9(1), 17-31.

Zhang, Shi and Artur B. Markman (1998), "Overcomming the Early Entrant Advantage: The Role of Alignable and Nonalignable Differences," Journal of Marketing Research, 35(November), 413-426. 